\title{
Contributions
}

Tobias S. Blattner and Jonathan M. Swarbrick*

\section{Monetary Policy and Cross-Border Interbank Market Fragmentation: Lessons from the Crisis}

https://doi.org/10.1515/bejm-2019-0097

Received May 10, 2019; accepted August 26, 2020

\begin{abstract}
We present a two-country model featuring risky lending and crossborder interbank market frictions. We find that (i) the strength of the financial accelerator, when applied to banks operating under uncertainty in an interbank market, will critically depend on the economic and financial structure of the economy; (ii) adverse shocks to the real economy can be the source of banking crisis, causing an increase in interbank funding costs, aggravating the initial shock; and (iii) asset purchases and central bank long-term refinancing operations can be effective substitutes for, or supplements to, conventional monetary policy.
\end{abstract}

Keywords: cross-border capital flows, financial frictions, interbank market, monetary union, unconventional monetary policy

JEL classification: E44, E52, F32, F36

Tobias S. Blattner, The views expressed herein are those of the authors and do not necessarily reflect those of the Eurosystem.

Jonathan M. Swarbrick, The views expressed in this paper are those of the authors. No responsibility for them should be attributed to the Bank of Canada.

*Corresponding author: Jonathan M. Swarbrick, Bank of Canada, 234 Wellington Street West, Ottawa, ON, K1A 0G9, Canada, E-mail: jswarbrick@bankofcanada.ca. https://orcid.org/00000002-1019-5345

Tobias S. Blattner, European Central Bank, Sonnemannstrasse 20, 60314, Frankfurt am Main, Hessen, Germany, E-mail: tobias.blattner@ecb.europa.eu 


\section{Introduction}

In the years following the global financial and the euro area sovereign debt crisis, the process of financial integration in the euro area moved into reverse as firms and households in the southern European periphery started to face much higher borrowing costs than their counterparts in the northern core. One of the key channels at the heart of this financial fragmentation was the interbank market, where the costs of cross-border lending rose sharply, and volumes fell dramatically, in particular in peripheral economies, thereby likely having contributed to reinforcing the macroeconomic fallout from the sharp collapse in aggregate demand. Although market segregation gradually receded over the past few years, probably also thanks to the actions taken by the European Central Bank (ECB), normal market functioning has not yet been fully restored. At face value, these facts contradict the predictions of standard open-economy models in which complete financial markets can be expected to facilitate, rather than to mute, effective risk-sharing and thereby help temper the adverse effects of asymmetric shocks.

Against this background, and with a view to improving our understanding of recent events, this article analyses the role of frictions in the interbank market of a currency union and examines how unconventional monetary policy measures may mitigate, or offset, the effects such frictions may have on financial conditions and, ultimately, on output and inflation. To this aim, we develop, calibrate and simulate a two-country dynamic stochastic general equilibrium (DSGE) model in which lending banks obtain funds from both domestic and foreign savings banks to refinance mortgage and private-sector business loans, but where interbank lending is subject to both borrower and country-specific idiosyncratic risk. Using this framework, we show that (i) the strength of the financial accelerator, when applied to banks operating under uncertainty in an interbank market, will critically depend on the economic and financial structure of the economy; (ii) adverse shocks to the real economy can be the source of banking crises, causing an increase in the interbank funding costs, aggravating the initial shock; and (iii) asset purchase policies and central bank long-term refinancing operations can both be an effective substitute, or complement, to changes in the conventional monetary policy instrument.

The interbank market plays a pivotal role in the euro area. Its smooth functioning is central for banks to cope efficiently with idiosyncratic liquidity shocks and to ensure a uniform transmission of the common monetary policy stance. Frictions in the interbank market may blur the signal coming from monetary policy and ultimately hamper its transmission. One reason why interbank markets may 
not operate efficiently has to do with transaction costs: owing to the unsecured lending nature of the market, and its over-the-counter (OTC) structure, ${ }^{1}$ trading relationships are often plagued by asymmetric information, counterparty risk, and search and monitoring costs (see e.g., Afonso, Kovner, and Schoar 2011; Flannery 1996). As a result, banks' wholesale market funding costs may differ across the currency union, and some banks may face hard borrowing constraints, which could affect both credit supply and the ultimate borrowing conditions of the nonfinancial sector. This also means that interbank market rates may be insufficient to characterize the monetary policy stance, even at times away from the effective lower bound.

These frictions are particularly relevant in cross-border transactions, where differences in banking supervision up until the introduction of the Single Supervisory Mechanism (SSM) in 2014, ${ }^{2}$ the state of the business cycle, insolvency laws or accounting standards may obfuscate the evaluation of the creditworthiness of foreign banks and expose lenders to uncertain counterparty risk. Freixas and Holthausen (2005) show that such market imperfections may cause liquidity shortages or the payment of interest rate premia that reflect the adverse selection of borrowers across countries. In crisis times, these effects may become even more visible. Using bank-to-bank loan-level data from TARGET2 ${ }^{3}$, Abbassi et al. (2014) find that for the same borrower on the same trading day, and after controlling for lender and borrower fixed effects, cross-border loans were up to 25 basis points more expensive than domestic loans in the first three months following the collapse of the former investment bank Lehman Brothers in 2008. De Andoain, Hoffmann, and Manganelli (2014) estimate that the premium charged to banks in more stressed economies spiked even more dramatically, reaching over 63 basis points. The presence of risk premia unrelated to the specific borrower suggests that information asymmetry constraints are important and that factors other than direct counterparty risks may also drive pricing behavior in interbank markets. Despite the empirical studies quantifying the effects of financial fragmentation, the precise source of these cross-border frictions remains an open question. A common view is that the risk of cross-border lending, particular to stressed economies, was being

1 Electronic trading accounted for less than 10\% of total unsecured transactions in 2014 (ECB 2015).

2 Even after the introduction of the SSM, national competent authorities retain discretion in applying common rules (see Nouy 2017).

3 TARGET2 is the Eurosystem's payment and settlement system and carries out more than $90 \%$ of all fund flows between pairs of credit institutions in the euro area. 
reassessed in the presence of imperfect information ${ }^{4}$. This view motivates the inclusion of an additional monitoring cost in the cross-border interbank market that rises in the face of heightened risk.

Cross-border interbank lending has been and continues to be an important element of the financial structure in the euro area. Prior to the outbreak of the global financial crisis, more than half of the average daily turnover in the unsecured market was with non-domestic euro area counterparts (ECB 2009a). Strong credit growth in parts of the euro area, buoyant financial innovation and lax financial regulation all contributed to an increasing reliance on confidencesensitive wholesale funding, with banks in current account surplus countries providing funding to banks in current account deficit countries (see van Rixtel and Gasperini 2013). After the outbreak of the crisis, the share of cross-border interbank lending fell dramatically to just over $25 \%$ in 2013 before recovering again to reach levels around 40\% in 2014, the latest available figures according to the ECB (ECB 2015).

These sharp variations in the funding structure of banks - broadly speaking the mix between wholesale and deposit funding - may have had severe repercussions on their operations and their willingness and ability to extend credit to the non-financial sector. Several empirical studies document that banks whose liabilities are mainly sticky household deposits, which are often protected by generous government insurance schemes, continued to lend in the aftermath of the crisis, whereas banks that relied predominantly on debt funding fared worse (Cornett et al. 2011; Demirgüç-Kunt and Huizinga 2010; Ivashina and Scharfstein 2010). In other words, wholesale funding, and cross-border funding in particular, makes banks more vulnerable to changes in market financing conditions with possibly strong repercussions on bank lending. These studies therefore tend to suggest that real shocks may be amplified, and financial shocks accelerated, by banks' structural recourse to wholesale financing.

Despite its empirical relevance, however, few efforts have been undertaken to study the main mechanisms and propagation channels of the interbank market in a structural model of the macroeconomy. Indeed, financing frictions were long absent in a general equilibrium context. The dominance of the Modigliani-Miller theorem (1958) that the financing structure of a firm is irrelevant for its value confined the analysis to real and nominal frictions in the wider economy (Christiano, Eichenbaum, and Evans 2005; Smets and Wouters 2007). The seminal work by Bernanke, Gertler, and Gilchrist (1999) and the subsequent contributions by

4 Imperfect information in relation to growth potential and the future profitability of destination banks, and with respect to the possible implications of the heightened sovereign risk (see Al-Eyd and Berkmen 2013; IMF 2013). 
Christiano, Motto, and Rostagno (2003, 2010, 2014) and Iacoviello (2005) made financial factors acceptable, and even desirable, in workhorse general equilibrium models. Their studies showed that asymmetric information, agency problems and borrowing constraints are important factors in driving and amplifying business cycles.

Yet, less progress has been made in understanding the impact of the financing structure of banks on lending conditions of the private sector and, hence, on aggregate output and inflation. In the pioneering work of Bernanke, Gertler, and Gilchrist (1999) and Christiano, Motto, and Rostagno (2003), and in work that followed (cf. Christensen and Dib 2008; De Graeve 2008; Goodfriend and Mccallum 2007), banks were either relegated to act as simple intermediaries between savers and borrowers or were operating under perfect competition.

It was only more recently that a more prominent role was given to banks in general equilibrium models. Gerali et al. (2010) and Darracq Paries, Sørensen, and Rodriguez-Palenzuela (2011) illustrate the effects of imperfect competition in the banking industry on credit spreads and show that changes in banks' leverage ratio can impact loan supply conditions. However, in these models, banks can obtain funding in a frictionless interbank market at the rate set by the central bank. Others have made attempts to model the interbank market more explicitly. Gertler and Kiyotaki (2010), building on Kiyotaki and Moore (1997), introduce a borrowing constraint in the interbank market by assuming that banks may divert borrowed assets for personal gain, causing a spread between lending and deposit rates. In the face of an adverse shock, this spread widens, which raises the cost of credit of firms, affecting real activity.

Dib (2010) and de Walque, Pierrard, and Rouabah (2010) include an interbank market in which, due to an implicit enforceability problem, borrowing banks can choose an optimal level of default, ${ }^{5}$ and where banks must hold a regulatory level of capital. Calibrated for the US economy, both papers show that bank capital attenuates, rather than amplifies, the real effects of shocks in this framework. Hilberg and Hollmayr (2011) incorporate a secured interbank market into an otherwise standard DSGE model and study the impact of central bank collateral policy on interbank lending rates. They show that a change in the haircut applied to central bank refinancing operations can be effective in steering interbank rates, but that the presence of an interbank market also attenuates the effects of conventional monetary policy. Similarly, Carrera and Vega (2012) model the interactions between banks' reserve requirements and interbank lending activity, which they assume is costly due to monitoring costs. They find that an increase in

5 That is, default is not related to banks' own idiosyncratic risks but a choice variable subject to an exogenous cost of default. 
required reserves increases demand in the competitive interbank market and pushes up the interest rate charged on these operations as lending banks will have to pay higher monitoring costs. Funding conditions in the interbank market then trickle down to lending and deposit rates, affecting real activity. In the framework of Carrera and Vega (2012), changes in reserve requirements are therefore qualitatively similar to traditional changes in policy rates.

Cross-border interbank lending, by contrast, has been largely ignored so far in the literature. In't Veld and van Lelyveld (2014) examine the role of international capital flows in the boom-bust cycle in Spain by allowing borrowing-constrained households to borrow directly from foreign lenders. Using an estimated threecountry model, they find that the convergence of interest rates in Spain to the levels prevailing in other euro area Member States, a loosening of collateral constraints as well as falling risk premia on Spanish housing and capital has fueled the Spanish housing boom. In similar spirit to our paper, Ueda (2012) studies the international propagation of shocks in an open economy model in which banks lend both domestically and internationally. Whereas intermediaries in our model face a single-layer credit constraint with two parts: a cross-border cost of credit that increases in domestic risk, and the Bernanke, Gertler, and Gilchrist (1999) financial accelerator; Ueda (2012) introduces nested credit constraints so both firms and intermediaries face an external finance premium. The authors use this to assess the necessary conditions to cause a global economic downturn, whereas we focus on the role of policy when cross-border frictions are present. Poutineau and Vermandel (2015) model the banking sector explicitly in a two-country DSGE model. Contrary to Quint and Rabanal (2014), who study the optimal design of macroprudential policies in the euro area in a two-country DSGE model, they allow for cross-border lending to firms and banks. They find that cross-border loans amplify the propagation of country-specific shocks. Dräger and Proaño (2015) also allow for cross-border banking where an international wholesale branch is collecting deposits from across the currency union and distributes them to retail banks in the two countries. Although their model does not give rise to interbank flows, similar to Poutineau and Vermandel (2015), they find that cross-border banking amplifies the effects of exogenous shocks in a currency union.

In this article, we try to bring the various strands of the literature together by incorporating credit risk in the interbank market of a currency union in a New Keynesian two-country, two-sector model with sticky prices, habits in consumption and investment adjustment costs. There are two types of banks in each country: savings banks, which have excess liquidity that they are willing to trade across borders in the interbank market, and lending banks, which operate under a structural liquidity deficit and require funding that they can obtain from the unsecured area-wide interbank market. Following the costly state verification 
framework of Bernanke, Gertler, and Gilchrist (1999), lending banks face idiosyncratic loan return shocks that are unobservable from the point of view of savings banks. A positive probability of default gives rise to an external finance premium that depends on the leverage of the borrower.

In addition, lending banks face a risk premium when taking a position in the cross-border interbank market. This second friction is in the same spirit as the external financial intermediation premium in Christoffel, Coenen, and Warne (2008), but tailored to the features of an interbank market: when the risk in the domestic economy increases, foreign lenders demand a higher rate of interest visà-vis the borrower from that country as counterparty risk rises, thereby driving a further wedge between the policy rate and interbank lending rates.

We use our model to answer three important questions: (1) how is the transmission of monetary policy in a currency union affected when financing conditions in the interbank market depend on the quality of banks' balance sheets; (2) how do asymmetric shocks to the value of assets propagate through a currency union when savings banks differentiate between domestic and foreign borrowers in the interbank market; and (3) how effective are some of the measures central banks have taken in the recent past to address funding bottlenecks in the interbank market?

Regarding the first question, we find that our model exhibits the financial accelerator effect (see Bernanke, Gertler, and Gilchrist 1999) in the face of a common monetary policy shock but that, compared to previous findings in the literature, there are noticeable differences in the way our model can give rise to changes in the transmission of monetary policy. In particular, compared to a situation where the financial accelerator operates directly at the balance sheet of firms, the strength and at times also the direction of propagation crucially depends on the share of saver households in the economy, the asset composition of lending banks' balance sheets and the degree of competition in the lending market.

Regarding the second question, our model is able to replicate some of the key features of the financial crisis that resulted in a segmented interbank market. ${ }^{6}$ We show that capital flows resulting from international financial integration can be highly procyclical, fluctuating in response to business cycles, thereby raising financial and economic fragility even before a crisis emerges, mainly by fostering credit growth. This means that in the wake of an adverse shock to the value of assets in one country, the rate charged by foreign lenders in the common interbank

6 In our model we focus on loan return risk. Ultimately, the implications of our findings are more broad based and less dependent on the ultimate source of risk. For example, the sharp increase in spreads paid by banks in stressed Member States during the sovereign debt crisis (see e.g., De Andoain, Hoffmann, and Manganelli 2014) works through the same channel, that is, a (perceived) deterioration in the quality of banks' balance sheets. 
market will rise as banks' balance sheets deteriorate amid a fall in the collateral value. The increase in the interbank funding cost of banks in this economy offsets, to some extent, the effort by the central bank to stimulate the (area-wide) economy by lowering the policy rate in response to the initial shock. That is, compared to a model without cross-border interbank lending, and contrary to union-wide shocks, monetary policy will be less effective. Moreover, as foreign funding becomes more expensive, the economy that draws the shock is forced to improve its trade balance more sharply relative to the case without financial frictions.

Finally, we study the effectiveness of two of the ECB's recent non-standard measures. We find that providing long-term refinancing operations (LTROs) to banks increases the effectiveness of monetary policy per unit of stimulus - that is, LTROs empower conventional monetary policy. The second policy focuses on the ECB's asset-backed securities purchase programme (ABSPP) that is particularly well suited to study in our model economy. Although securitization is more complex in practice, the ultimate effects of the ABSPP can be well approximated by assuming that the central bank purchases risky loans directly from banks, thereby freeing up bank balance sheet capacity and reducing their funding costs in the interbank market. We find that asset purchases in the form of loans, either directly or through purchases of ABS, can be an effective substitute, or complement, to reductions in the key policy rate.

The rest of the paper is organized as follows. Section 2 lays out the model setup. Section 3 discusses model calibration and Section 4 presents numerical simulations, illustrating the role of the interbank market in driving the dynamics of the model. Section 5 analyzes the effects of the ECB's policy measures, while Section 6 offers some concluding remarks.

\section{The Model}

The model is made up of two economies that share a single currency and monetary policy. In each economy there are two types of households, savers and borrowers, monopolistic competitive firms, savings and lending banks as well as a fiscal authority. The two economies, of size $n$ and $(1-n)$, trade in both non-durable consumption goods and financial services in the form of interbank credit. In the following, we describe the decision-making problems of the economic agent's resident in the home economy. Unless otherwise stated, analogous conditions hold for the foreign economy. The time notation refers to the period in which the value is determined. 


\subsection{Households}

The household sector is made up of a mass $\lambda \in[0,1]$ of patient households with discount factor $\beta$ and $(1-\lambda)$ of impatient households with discount factor $\beta^{B}<\beta$. The patient households are referred to as the savers and the impatient households as the borrowers.

\subsubsection{Savers}

The saver household $h \in[0, \lambda]$ chooses the level of consumption of non-durable goods $C_{h, t}$, hours worked $L_{h, t}$, the housing stock $D_{h, t}$, and bank deposit savings $S_{h, t}$ to maximize its lifetime utility

$$
\mathbb{E}_{t} \sum_{s=0}^{\infty} \beta^{s}\left\{\varrho \ln \left(C_{h, t+s}-\kappa C_{t+s-1}\right)+(1-\varrho) \ln \left(D_{h, t+s-1}\right)-\frac{L_{h, t+s}^{1+\phi}}{1+\phi}\right\}
$$

subject to the nominal budget constraint

$$
P_{t}^{C} C_{h, t}+P_{t}^{D}\left(D_{h, t}-\left(1-\delta_{D}\right) D_{h, t-1}\right)+S_{h, t} \leq R_{t-1}^{S} S_{h, t-1}+W_{t} L_{h, t}+\pi_{t}-T_{t},
$$

where $\varrho$ determines the relative weight of non-durable consumption in the saver's utility and $\kappa$ the degree of external habit formation in consumption. The parameter $\phi$ refers to the inverse of the Frisch labor supply elasticity. $P_{t}^{C}$ and $P_{t}^{D}$ are the price indices for consumption and housing goods respectively (see derivation below). $\delta_{D} \in(0,1)$ denotes the depreciation rate of housing. The saver can deposit his savings in domestic banks which pay the risk-free nominal interest rate $R_{t}^{S}$. Finally, the saver provides labor at the flexible nominal wage rate $W_{t}$ and owns the stock of net wealth of the economy, except for housing that is in part also owned by the borrower household, therefore receiving profits $\pi_{t}$ from the banking and corporate sector and paying lump sum taxes $T_{t}$.

Because saver households have the same preferences over consumption, housing, labor, savings and investment, and are assumed to have the same initial wealth, we focus on a representative saver from now onwards and drop the $h$ subscript. The saver household chooses the optimal inter-temporal plan subject to the budget constraint, resulting in a set of familiar first-order conditions that will hold in equilibrium:

$$
\begin{aligned}
1 & =R_{t}^{S} \mathbb{E}_{t}\left[\frac{\Lambda_{t, t+1}}{\prod_{t+1}^{C}}\right] \\
\lambda_{t}^{C} Q_{t}^{D} & =\beta \mathbb{E}_{t}\left[\lambda_{t}^{D}+\left(1-\delta_{D}\right) Q_{t+1}^{D} \lambda_{t+1}^{C}\right]
\end{aligned}
$$




$$
w_{t}=\frac{L_{t}^{\phi}}{\lambda_{t}^{C}}
$$

where $\lambda_{t}^{C}$ and $\lambda_{t}^{D}$ are the marginal utilities of consumption and housing respectively, and $\Lambda_{t, t+1} \equiv \beta \frac{\lambda_{t+1}^{c}}{\lambda_{t}^{c}}$ is the real stochastic discount factor over the interval $[t, t+1]$. Because housing, $D_{h, t}$, is chosen one period in advance, the marginal utility, $\lambda_{t}^{D}$, is discounted by $\beta$. Equations (2.1) and (2.2) are the Euler equations implied by the demand for domestic deposits and the demand for housing respectively. The relative price of housing is given by $Q_{t}^{D} \equiv \frac{P_{t}^{D}}{P_{t}^{C}}$ and inflation is defined by $\Pi_{t}^{C} \equiv P_{t}^{C} / P_{t-1}^{C}$. The real wage rate is given by $w_{t}=W_{t} / P_{t}^{C}$, which is equal to the marginal rate of substitution between labor and consumption in equilibrium (2.3).

\subsubsection{Borrowers}

Preferences of the borrowers are the same as those of the saver except for the difference in the time discounting. Borrower household $h \in[\lambda, 1]$ maximizes

$$
\mathbb{E}_{t} \sum_{s=0}^{\infty} \beta_{B}^{s}\left\{\varrho \ln \left(C_{h, t+s}^{B}-\kappa C_{t+s-1}^{B}\right)+(1-\varrho) \ln \left(D_{h, t+s-1}^{B}\right)-\frac{\left(L_{h, t+s}^{B}\right)^{1+\phi}}{1+\phi}\right\},
$$

subject to the nominal budget constraint

$$
P_{t}^{C} C_{h, t}^{B}+P_{t}^{D}\left(D_{h, t}^{B}-\left(1-\delta_{D}\right) D_{h, t-1}^{B}\right)+R_{t-1}^{M} C R_{h, t-1}^{H H} \leq C R_{h, t}^{H H}+W_{t} L_{h, t}^{B} .
$$

The notations are identical to the saver household and where the superscript $B$ characterizes variables specific to borrowers. Following Kiyotaki and Moore (1997) and Iacoviello (2005), borrowers finance their consumption of housing with credit $C R_{h, t}^{H H}$ obtained from lending banks at the mortgage rate $R_{h, t}^{M}$. Banks impose collateral constraints of the form

$$
C R_{h, t}^{H H} \leq m \mathbb{E}_{t}\left[P_{t+1}^{D}\right] D_{h, t}^{B} \frac{1}{R_{t}^{M}} .
$$

That is, banks will only lend to the point that total repayment is a fraction $m$ of the expected housing value, with a view to ensuring that households will not default the following period. Under uncertainty, the borrowers could self-insure in some states of the world by borrowing below the limit to protect against the effects of adverse shocks. To avoid issues introduced by occasionally binding constraints, we therefore follow Iacoviello (2005) and choose the parameter $m$ to minimize the probability of this occurring.

The decision-making problems of the representative borrower household lead to a labor supply condition analogous to that of the saver household. The housing investment decision leads to an Euler equation of the form 


$$
\lambda_{t}^{C, B} Q_{t}^{D}=\beta \mathbb{E}_{t}\left[\lambda_{t}^{D, B}+\left(1-\delta_{D}-m\right) Q_{t+1}^{D} \lambda_{t+1}^{C, B}\right]+\mathbb{E}_{t}\left[\lambda_{t}^{C, B} Q_{t+1}^{D} \frac{\Pi_{t, t+1}^{C}}{R_{t}^{M}}\right] m .
$$

This differs from that of the savers due to a wedge between the marginal utility of consumption and the marginal benefit of housing, introduced by the borrowing constraint. In the case that $m=0$, so there is no constraint, the two expressions are analogous.

\subsection{Firms}

We introduce nominal rigidities in the price of consumption goods following Calvo (1983). To this end, we assume there are two types of firms in the model economy: intermediate goods firms that are price takers in perfect competition, and final goods firms that operate under monopolistic competition. There is 'price-stickiness' introduced in the latter sector as only a fixed proportion of firms is able to update prices each period.

\subsubsection{Intermediate Goods Firms}

Each intermediate goods producer purchases capital goods $K_{t}^{D}$ and hires labor $L_{t}^{D}$ to produce a homogeneous output $Y_{w, t}$ subject to a Cobb-Douglas production function

$$
Y_{w, t}=A_{t} Z_{t}\left(K_{t-1}^{D}\right)^{\alpha}\left(L_{t}^{D}\right)^{1-\alpha},
$$

where the superscript $D$ indicates factor demand and $A_{t}$ and $Z_{t}$ are, respectively, stationary union-wide and country-specific total factor productivity shocks. Both are modeled as $\operatorname{AR}(1)$ processes: $a_{t}^{A}=\rho^{A} a_{t-1}^{A}+\varepsilon_{t}^{A}$ where $a_{t} \equiv \ln A_{t}$ and with a normal i.i.d. shock $\varepsilon_{t}^{A}$. There is an equivalent process for $z_{t} \equiv \ln Z_{t}$. Taking the aggregate real wage index $w_{t}$ as given, the profit maximization implies labor demand is given by

$$
w_{t}=(1-\alpha) \frac{P_{w, t}}{P_{t}^{C}} \frac{Y_{w, t}}{L_{t}^{D}}
$$

where $P_{w, t}$ is the price at which the output is sold to all final goods firms. This implies that $P_{w, t} / P_{t}^{C}=m c_{t}$ is the real marginal cost in the final goods sector. New capital is purchased from capital producers at the end of the period at real price $Q_{t}$. Due to the constant returns to scale in production, capital is paid at the marginal product 


$$
r_{t}^{k}=\alpha \frac{P_{w, t}}{P_{t}^{C}} \frac{Y_{w, t}}{K_{t-1}^{D}}
$$

If capital depreciates at rate $\delta_{K}$, it follows that the gross nominal return on capital is given by

$$
R_{t}^{K}=\frac{r_{t}^{K}+\left(1-\delta_{K}\right) Q_{t}^{K}}{Q_{t-1}^{K}} \Pi_{t-1, t}^{C}
$$

The end-of-period capital purchase decision of firms will ensure the expected discounted gross return on capital will equal the expected discounted cost of funds. We will return to this in the discussion of the banking sector below.

\subsubsection{Capital Producers}

For convenience, and without loss of generality, we introduce perfectly competitive capital producers that make new capital goods and sell to firms. Capital follows the law of motion

$$
K_{t}=\left(1-\delta_{K}\right) K_{t-1}+\left[1-S\left(\frac{I_{t}^{K}}{I_{t-1}^{K}}\right)\right] I_{t}^{K}
$$

where $I_{t}^{K}$ is investment and, following Christiano, Eichenbaum, and Evans (2005), the function $S(\cdot)$ is increasing in changes to investment, given by

$$
S\left(\frac{I_{t}^{K}}{I_{t-1}^{K}}\right)=\frac{\zeta^{K}}{2}\left(\frac{I_{t}^{K}}{I_{t-1}^{K}}-1\right)^{2}
$$

The capital producers solve

$$
\max _{I_{t}^{K}} \mathbb{E}_{t} \sum_{s=0}^{\infty} \Lambda_{t, t+s}\left(Q_{t+s}^{K}\left[1-S\left(\frac{I_{t+s}^{K}}{I_{t-1+s}^{K}}\right)\right] I_{t+s}^{K}-\frac{P_{t+s}^{P}}{P_{t+s}^{C}} I_{t+s}^{K}\right),
$$

where $P_{t}^{P}$ is the domestic producer price and $Q_{t}^{K}$ the real price of capital. This leads to the first-order condition

$$
\begin{aligned}
\frac{P_{t}^{P}}{P_{t}^{C}}= & Q_{t}^{K}\left(1-\frac{\zeta^{K}}{2}\left(\frac{I_{t}^{K}}{I_{t-1}^{K}}-1\right)^{2}-\zeta^{K}\left(\frac{I_{t}^{K}}{I_{t-1}^{K}}-1\right) \frac{I_{t}^{K}}{I_{t-1}^{K}}\right) \\
& +\mathbb{E}_{t}\left[\Lambda_{t, t+1} Q_{t+1}^{K} \zeta^{K}\left(\frac{I_{t+1}^{K}}{I_{t}^{K}}-1\right)\left(\frac{I_{t+1}^{K}}{I_{t}^{K}}\right)^{2}\right]
\end{aligned}
$$




\subsubsection{Final Goods Producers}

Each final goods producer firm $j$ purchases output from the intermediate goods sector at price $P_{w, t}$ and converts it into a differentiated good sold at price $P_{t}^{P}(j)$ to households, durable goods producers and the fiscal authority. Summing the demand schedules from each buyer (see Section 2.2.4) implies a total demand for good $j$ given by

$$
Y_{t}(j)=\left(\frac{P_{t}^{P}(j)}{P_{t}^{P}}\right)^{-\sigma} Y_{t}
$$

where $\sigma$ denotes the elasticity of substitution between the different varieties, assumed to be identical across the currency union. Every period, each firm faces a fixed probability $1-\xi$ that it will be able to update its price. Denoting the optimal price at time $t$ for good $j$ as $P_{t}^{\star}(j)$, the firms allowed to reoptimize prices maximize expected discounted profits by solving

$$
\max _{P_{t}^{\star}(j)} \mathbb{E}_{t} \sum_{k=0}^{\infty} \xi^{k} \frac{\Lambda_{t, t+k}}{P_{t+k}^{C}} Y_{t+k}(j)\left[P_{t}^{\star}(j)-P_{w, t+k}\right] .
$$

The solution to the price-setting problem yields a price $P_{t}^{\star}$ which is independent of the firm's history of prices and therefore optimal for all price setters. With real marginal cost given by $m c_{t}=\frac{P_{w, t}}{P_{t}^{c}}$ and producer price inflation denoted by $\Pi_{t}^{P} \equiv \frac{P_{t}^{P}}{P_{t-1}^{P}}$, we can write this as

$$
\frac{P_{t}^{\star}}{P_{t}^{P}}=\frac{\sigma}{\sigma-1} \frac{\mathbb{E}_{t} \sum_{k=0}^{\infty} \xi^{k} \Lambda_{t, t+k}\left(\Pi_{t, t+k}^{P} \mathbb{E}_{t} \sum_{k=0}^{\infty} \xi^{k} \Lambda_{t, t+k}\left(\Pi_{t, t+k}^{P} m\right)^{\sigma}\left(\Pi_{t, t+k}^{C}\right)^{-1} Y_{t+k}\right.}{.}
$$

Using the aggregate producer price index $P_{t}^{P}$ and the fact that all resetting firms will choose the same price, by the law of large numbers we can find the evolution of the price index as given by

$$
\left(P_{t}^{P}\right)^{1-\sigma}=\xi\left(P_{t-1}^{P}\right)^{1-\sigma}+(1-\xi)\left(P_{t}^{\star}\right)^{1-\sigma} .
$$

While the distribution of prices is not required to track the evolution of the aggregate price index, it implies a loss of output due to dispersion in prices. Final output is given by $Y_{t}=Y_{w, t} \frac{1}{\Delta_{t}}$ where price dispersion is given by

$$
\Delta_{t}=\frac{1}{J} \sum_{j-1}^{J}\left(\frac{P_{t}^{P}(j)}{P_{t}^{P}}\right)^{-\sigma}
$$


for non-optimizing firms $j=1, \ldots, J$. As a proportion $(1-\xi)$ of firms will optimize prices in period $t$ and knowing that the distribution of non-optimized prices will be the same as the overall distribution, price dispersion can be written as a law of motion:

$$
\Delta_{t}=\xi \Pi_{t}^{\sigma} \Delta_{t-1}+(1-\xi)\left(\frac{\Omega_{1, t}}{\Omega_{2, t}}\right)^{-\sigma} .
$$

\subsubsection{Consumption Good Producers}

Households purchase differentiated final goods and combine bundles of domestically produced goods and aggregate imports to produce the final consumption bundle according to

$$
C_{t}=\left[\left(\tau^{C}\right)^{\frac{1}{\theta_{C}}} H_{t}^{\frac{\theta_{C}-1}{\theta_{C}}}+\left(1-\tau^{C}\right)^{\frac{1}{\theta_{C}}} I M_{t}^{\frac{\theta_{C}-1}{\theta_{C}}}\right]^{\frac{\theta_{C}}{\theta_{C}-1}},
$$

where $\tau^{C}$ can be interpreted as the degree of home bias in household consumption expenditures, and $\theta_{C}$ is the elasticity of substitution between domestic and foreign produced goods (see Armington 1969). $H_{t}$ and $I M_{t}$ are bundles of differentiated domestic and foreign-produced goods which households combine into baskets of goods using

$$
\begin{aligned}
H_{t} & =\left(\int_{0}^{1} H_{t}(j)^{\frac{\sigma-1}{\sigma}} \mathrm{d} j\right)^{\frac{\sigma}{\sigma-1}} \\
I M_{t} & =\left(\int_{0}^{1} I M_{t}\left(j^{*}\right)^{\frac{\sigma-1}{\sigma}} \mathrm{d} j^{*}\right)^{\frac{\sigma}{\sigma-1}},
\end{aligned}
$$

where the asterisk indicates variables of the foreign country. The households purchase good $H_{t}(j)$ from producer $j \in(0,1)$ at price $P_{t}^{P}(j)$ to maximize (2.12) subject to total expenditure $P_{t}^{P} H_{t}=\int_{0}^{1} P_{t}^{P}(j) H_{t}(j) \mathrm{d} j$, with an equivalent problem for imports $\operatorname{IM}_{t}\left(j^{*}\right)$. This leads to Dixit and Stiglitz (1977) demand schedules

$$
\begin{aligned}
H_{t}(j) & =\left(\frac{P_{t}^{P}(j)}{P_{t}^{P}}\right)^{-\sigma} H_{t} \\
I M_{t}\left(j^{*}\right) & =\left(\frac{P_{t}^{I M}\left(j^{*}\right)}{P_{t}^{I M}}\right)^{-\sigma} I M_{t} .
\end{aligned}
$$

Equivalent conditions for the domestic demand of the investment good and government consumption good hold. We assume no pricing to market, which implies 
that $P_{t}^{I M}=P_{t}^{P^{\star}}$. The final goods firms take input prices as given and maximize their profits $P_{t}^{C} C_{t}-P_{t}^{P} H_{t}-P_{t}^{I M} I M_{t}$. Profit maximization yields the following demand schedules for the domestic bundle and aggregate imports:

$$
\begin{aligned}
H_{t} & =\tau^{C}\left(\frac{P_{t}^{P}}{P_{t}^{C}}\right)^{-\theta_{C}} C_{t} \\
I M_{t} & =\left(1-\tau^{C}\right)\left(\frac{P_{t}^{I M}}{P_{t}^{C}}\right)^{-\theta_{C}} C_{t} .
\end{aligned}
$$

This leads to the consumer price index $P_{t}^{C}$ given by

$$
P_{t}^{C}=\left[\tau^{C}\left(P_{t}^{P}\right)^{1-\theta_{C}}+\left(1-\tau^{C}\right)\left(P_{t}^{I M}\right)^{1-\theta_{C}}\right]^{\frac{1}{1-\theta_{C}}}
$$

\subsubsection{Housing Producers}

The price of durable housing goods can differ from that of consumption goods due to the presence of adjustment costs. To ensure that savers and borrowers observe the same house price, we let housing good producers augment the existing total stock, $D_{t}^{T} \equiv \lambda D_{t}+(1-\lambda) D_{t}^{B}$, according to the following law of motion:

$$
D_{t}^{T}=\left(1-\delta_{D}\right) D_{t-1}^{T}+\left[1-S\left(\frac{I_{t}^{D}}{I_{t-1}^{D}}\right)\right] I_{t}^{D}
$$

where we follow the same adjustment costs as faced in capital investment. The housing goods producers solve

$$
\max _{I_{t}^{D}} \mathbb{E}_{t} \sum_{s=0}^{\infty} \frac{\Lambda_{t, t+s}}{P_{t+s}^{C}}\left(P_{t+s}^{D}\left[1-S\left(\frac{I_{t+s}^{D}}{I_{t-1+s}^{D}}\right)\right] I_{t+s}^{D}-P_{t+s}^{P} I_{t+s}^{D}\right),
$$

which leads to the first-order condition

$$
\frac{P_{t}^{P}}{P_{t}^{C}}=Q_{t}^{D}\left(1-\frac{\zeta^{D}}{2}\left(\frac{I_{t}^{D}}{I_{t-1}^{D}}-1\right)^{2}-\zeta^{D}\left(\frac{I_{t}^{D}}{I_{t-1}^{D}}-1\right) \frac{I_{t}^{D}}{I_{t-1}^{D}}\right)+\mathbb{E}_{t}\left[\Lambda_{t, t+1} Q_{t+1}^{D} \zeta^{D}\left(\frac{I_{t+1}^{D}}{I_{t}^{D}}-1\right)\left(\frac{I_{t+1}^{D}}{I_{t}^{D}}\right)^{2}\right] .
$$

\subsection{Financial Intermediation}

There are two types of banks: savings banks that take deposits from domestic households and lend in the currency union-wide interbank market and lending 
banks that provide loans to both domestic firms and households and finance these using interbank borrowing and their own net worth. A financial friction emerges due to idiosyncratic loan return shocks faced by lending banks. Costly state verification leads to an external finance premium as in Bernanke, Gertler, and Gilchrist (1999). In addition, in light of the empirical evidence that borrower banks often have to pay a premium that reflects not borrower but country-specific risks when accessing the international interbank market (cf. Section 1), we add a further friction whereby cross-border interbank credit faces additional monitoring costs that depend on the prevailing risk in the lending market.

Savings banks operate under perfect competition with free entry, but aggregate shocks can lead to unexpected profits or losses. The banks are owned by the patient households who are paid all bank profits, or recapitalize banks if and when necessary. Lending banks face idiosyncratic shocks when extending credit to the real economy that are costly for creditors to observe. Limited liability implies that these banks earn profits in equilibrium. Lending banks are treated slightly differently to savings banks in that they pay a fixed dividend rate to ensure they cannot become fully self-funded, equivalent to the assumption of an exogenous exit rate or higher banker discounting (see e.g., Bernanke, Gertler, and Gilchrist 1999; Gertler and Kiyotaki 2010). The friction implies that equity is always more valuable than debt, without which banks would not pay dividends in equilibrium. Another difference is that savings banks can access central bank credit whereas lending banks cannot. This is in part motivated by the risk exposure and specialization of lending banks; savings banks are well diversified and the central bank requires a proportion of safe assets as collateral.

\subsubsection{Lending Banks}

There are many lending banks of unit mass indexed $b \in[0,1]$. They extend credit $C R_{t}$ to the non-financial sector, which they finance with domestic $I B_{t}^{H}$ and crossborder $I B_{t}^{F}$ interbank borrowing and net worth $N_{t}$ :

$$
C R_{t}=N_{t}+I B_{t}^{H}+I B_{t}^{F},
$$

where, following Poutineau and Vermandel (2015), $I B_{t}^{H}$ and $I B_{t}^{F}$ are chosen to maximize a constant elasticity of substitution (CES) Armington aggregator (see Armington 1969) of domestic and foreign interbank borrowing

$$
I B_{t}=\left[\left(\tau^{I B}\right)^{\frac{1}{\theta_{I B}}}\left(I B_{t}^{H}\right)^{\frac{\theta_{I B}-1}{\theta_{I B}}}+\left(1-\tau^{I B}\right)^{\frac{1}{\theta_{I B}}}\left(I B_{t}^{F}\right)^{\frac{\theta_{I I}-1}{\theta_{I B}}}\right]^{\frac{\theta_{I B}}{\theta_{I B}-1}},
$$


where $\tau^{I B}$ can be interpreted as a home bias in interbank borrowing and $\theta_{I B}$ is the elasticity of substitution between domestic and foreign borrowing. ${ }^{7}$ A non-zero $\theta_{I B}$ implies that domestic and foreign interbank borrowing are not perfect substitutes, rendering differences in lending rates. Maximization yields the following familiar demand schedules:

$$
\begin{aligned}
& I B_{t}^{H}=\tau^{I B}\left(\frac{R_{t}^{I B, H}}{R_{t}^{I B}}\right)^{-\theta_{I B}} I B_{t} \\
& I B_{t}^{F}=\left(1-\tau^{I B}\right)\left(\frac{R_{t}^{I B, F}}{R_{t}^{I B}}\right)^{-\theta_{I B}} I B_{t},
\end{aligned}
$$

where $R_{t}^{I B, H}$ is the lending rate on the domestic interbank market and $R_{t}^{I B, F}$ the rate on the cross-border market. Using these demand schedules and $R_{t}^{I B} I B_{t}=R_{t}^{I B, H} I B_{t}^{H}+R_{t}^{I B, F} I B_{t}^{F}$, composite interbank funding costs are given by

$$
R_{t}^{I B}=\left[\tau^{I B}\left(R_{t}^{I B, H}\right)^{1-\theta_{I B}}+\left(1-\tau^{I B}\right)\left(R_{t}^{I B, F}\right)^{1-\theta_{I B}}\right]^{\frac{1}{1-\theta_{I B}}} .
$$

When granting loans to the non-financial private sector, we assume that lending banks cannot diversify risk in their loan portfolio and that they experience idiosyncratic loan return shocks $\omega_{t}(b)$ that affect the value of the asset side of their balance sheets. ${ }^{8}$ The shocks are $\log$-normally distributed, $\log \left(\omega_{t}(b)\right) \sim \mathscr{N}\left(-\left(\sigma_{\omega, t}^{2} / 2\right), \sigma_{\omega, t}^{2}\right)$, with mean $\mathbb{E}_{t}\left[\omega_{t}\right]=1$ and standard deviation $\sigma_{\omega}$, which is time-varying and is modeled as an $\mathrm{AR}(1)$ process: $\log \left(\sigma_{\omega, t}\right)=\left(1-\rho_{\sigma}\right) \log \left(\sigma_{\omega, s s}\right)+\rho_{\sigma} \log \left(\sigma_{\omega, t-1}\right)+u_{\omega, t}$ and $u_{\omega, t} \sim \mathscr{N}\left(0, \sigma_{\sigma}\right)$.

After aggregate and idiosyncratic shocks hit the economy, net worth of lending banks evolves according to

$$
N_{t}(b)=\omega_{t}(b) R_{t}^{C R} C R_{t-1}(b)-R_{t-1}^{I B} I B_{t-1}(b),
$$

where $R_{t}^{C R}$ is the ex post return on banks' loan portfolio $C R_{t}$. Limited liability implies that if the realization of the shock is below a threshold value $\bar{\omega}_{t}$, then the lending bank will default on its interbank borrowing as they would otherwise be insolvent. This threshold value is found when setting $N_{t}(b)=0$ :

$$
\bar{\omega}_{t}(b)=\frac{R_{t-1}^{I B} I B_{t-1}(b)}{R_{t}^{C R} C R_{t-1}(b)} .
$$

7 This setup provides incentive for banks to borrow from both domestic and foreign banks as observed in the data and is analogous to preferences over domestic and foreign produced goods in the trade part of the model.

8 Thus allowing us to study imperfect diversification in a tractable way. 
The lending banks will pay the saver households a fixed dividend rate, investing all remaining profits in their own net worth. It is assumed that a defaulting bank will exit but that for every exiting bank, a new one enters and is given a small startup fund by the other banks. This ensures that the number of banks is held constant at any point in time. The idiosyncratic loan return and default leads to a distribution of lending banks over all possible values of net worth.

The loan portfolio is comprised of mortgage loans to households $C R_{t}^{H H}$ and lending to firms $C R_{t}^{F}$. The former are treated as nominal one-period bonds, whereas for the latter it is convenient to consider it as state-contingent debt, ${ }^{9}$ offering ex post, gross, nominal return given by $R_{t}^{K}$ as defined above. The lending banks specify a contract for interbank funds subject to participation constraints given in the following section. After detailing the solution to the savings banks' problem, we discuss the contract that determines the demand for interbank credit and the supply of credit to the non-financial private sector.

\subsubsection{Savings Banks}

A representative savings bank has access to the central bank's liquidity providing operations $C B_{t}$, raises deposits $S_{t}$ from patient households and extends both domestic $I B_{t}^{H}$ and cross-border $I B_{t}^{F^{\star}}$ interbank loans:

$$
S_{t}+C B_{t}=I B_{t}^{H}+I B_{t}^{F^{\star}} .
$$

Solving the profit maximization problem,

$$
\max _{I B_{t}^{H}, I B_{t}^{F}, S_{t}, C B_{t}} \mathbb{E}_{t} \sum_{s=0}^{\infty} \frac{\Lambda_{t, t+s}}{P_{t+s}^{C}}\left(\tilde{R}_{t+s+1}^{I B, H} I B_{t+s}^{H}+\tilde{R}_{t+s+1}^{I B, F} I B_{t+s}^{F}-R_{t+s}^{S} S_{t+s}-R_{t+s} C B_{t+s}\right),
$$

subject to the balance sheet, leads to the zero-arbitrage condition

$$
\mathbb{E}_{t}\left[\frac{\Lambda_{t, t+1}}{P_{t+1}^{C}} R_{t}^{S}\right]=\mathbb{E}_{t}\left[\frac{\Lambda_{t, t+1}}{P_{t+1}^{C}} \tilde{R}_{t+1}^{I B}\right],
$$

where $\tilde{R}_{t}^{I B}$ is the ex post return on interbank lending, and the condition $R_{t}^{S}=R_{t}$ under standard one-period central bank finance, where $R_{t}$ is the policy rate. The savings bank can only observe the loan return of the lending bank if it pays a proportional monitoring fee $\mu$. As shown in Townsend (1979), the implication of this costly state verification is that the fee will only be paid in the event of default,

9 As in Gertler and Kiyotaki (2010). This is equivalent to the firms using state-contingent debt to purchase the capital themselves. It is natural to assume that debt contracts are state-contingent due to costless monitoring and enforcement and the risk neutrality of the lender. 
with all other debtors paying the same interest rate. Interbank lending is subject to a participation constraint that accounts for the distribution of idiosyncratic shocks drawn by lending banks and the aggregate state of the economy.

For the domestic market, the savings banks require the expected real return from granting each interbank loan to be equal to their expected real funding rate, using the household Euler equation. This can be written as

$$
\begin{aligned}
1= & \mathbb{E}_{t}\left[\frac{\Lambda_{t, t+1}}{\Pi_{t+1}^{C}}\left[1-F\left(\bar{\omega}_{t+1}(b), \sigma_{\omega, t+1}\right)\right] R_{t}^{I B, H}(b)\right] \\
& +\mathbb{E}_{t}\left[\frac{\Lambda_{t, t+1}}{\Pi_{t+1}^{C}}(1-\mu) \int_{0}^{\bar{\omega}_{t+1}(b)} \omega R_{t+1}^{C R} \frac{C R_{t}(b)}{I B_{t}^{H}(b)+I B_{t}^{F}(b)} d F\left(\omega, \sigma_{\omega, t+1}\right)\right],
\end{aligned}
$$

where $F(\bar{\omega}(b), \sigma) \equiv \int_{0}^{\bar{\omega}(b)} f\left(\omega ; \frac{-\sigma^{2}}{2}, \sigma^{2}\right) d \omega$ is the cumulative density function up to $\bar{\omega}(b)$, with probability density function $f\left(\omega ; \frac{-\sigma^{2}}{2}, \sigma^{2}\right)$. Note that this implies that the value $F\left(\bar{\omega}_{t+1}(b), \sigma_{\omega, t+1}\right)$ is the probability of default. The first part of the term on the right-hand side of equation (2.28) is the expected discounted return from the $1-F(\cdot)$ non-defaulted loans, of which the agreed lending rate is $R_{t}^{I B, H}$. The second part is the expected discounted recovered value of post-defaulted loans, subject to the cost $\mu$. The interbank loans are used to refinance non-financial sector loans with a rate of return $\omega R_{t+1}^{C R}$ where $\omega$ is the idiosyncratic loan return shock, noting that the lower the leverage, $\frac{C R_{t}(b)}{I B_{t}^{H}(b)+I B_{t}^{F}(b)}$, the higher the return to the creditor. Equation (2.28) highlights the central role that the leverage plays in determining the interest spread in the banking sector; the more highly borrowers are leveraged, the higher the rate of default and the lower the expected return from defaulters. Because all banks will choose the same leverage ratio, individual bank net worth does not affect the interest rate paid on credit, and equation (2.28) will therefore also hold if the index $b$ is dropped, with the variables treated as the aggregate averages. ${ }^{10}$

When taking positions in the cross-border interbank market, we assume that savings banks incur additional monitoring costs $\Gamma_{I B, t}$ that are increasing in the level of risk within the economy. Such costs reflect factors such as asymmetric information, counterparty risk as well as differences in cross-border macroeconomic conditions. Specifically, it is given by

$$
\Gamma_{I B, t}=\zeta_{\sigma}\left(\frac{\sigma_{\omega, t}^{\star}}{\sigma_{\omega}}-1\right),
$$

10 As banks are atomistic, $\Lambda_{t, t+1}$ is independent of the idiosynctratic shock $\omega_{t+1}(b)$ drawn by the bank, thus implying irrelevance of $N_{t}(b)$ and allowing aggregation. 
which causes an increase to the monitoring costs following a shock to the variance of the idiosyncratic loan return shock. That is, country-specific risk shocks will cause an increase in the finance premium of borrowing banks in the cross-border interbank market ${ }^{11}$. Therefore, the participation constraint for international interbank loans can be expressed as

$$
\begin{aligned}
1= & \mathbb{E}_{t}\left[\frac{\Lambda_{t, t+1}}{\Pi_{t+1}^{C}}\left(1-\Gamma_{I B, t}\right)\left[1-F\left(\bar{\omega}_{t+1}^{\star}(b), \sigma_{\omega, t+1}^{\star}\right)\right] R_{t}^{I B, F, *}(b)\right] \\
& +\mathbb{E}_{t}\left[\frac{\Lambda_{t, t+1}}{\Pi_{t+1}^{C}}(1-\mu) \frac{G\left(\bar{\omega}_{t+1}^{\star}(b), \sigma_{\omega, t+1}^{\star}\right)}{\bar{\omega}_{t+1}^{\star}(b)} R_{t}^{C R, \star}(b) \frac{C R_{t}^{\star}(b)}{I B_{t}^{H, *}(b)+I B_{t}^{F, *}(b)}\right],
\end{aligned}
$$

where $G\left(\bar{\omega}_{t+1}^{\star}(b), \sigma_{\omega, t+1}^{\star}\right) \equiv \int_{0}^{\bar{\omega}_{t}(b)} \omega d F\left(\omega, \sigma_{t}\right)$ and $F_{t}^{b}=F\left(\bar{\omega}_{t}(b), \sigma_{t}\right)$. As with (2.28), the first part of the right-hand side of equation (2.30) is the discounted value of non-defaulted interbank loans, although this now includes the cross-border monitoring cost, $\Gamma_{I B, t}{ }^{12}$. This participation constraint implies a spread in the crossborder interbank market $\frac{R_{t}^{I B, F, \star}(b)}{R_{t}^{S}}$ that is a function of the monitoring $\operatorname{cost} \Gamma_{I B, t}$, which itself is increasing in the standard deviation of the loan return shock: a higher $\sigma \omega, t$ will increase the risks of default by making lower realization of $\omega t(b)$ more likely.

\subsubsection{Interbank Credit Market}

To model the over-the-counter structure of the interbank market, we follow Bernanke, Gertler, and Gilchrist 1999 in our treatment of the lending contract. The lending banks choose credit to the non-financial private sector $C R_{t}$, the volume of interbank lending $I B_{t}^{H}$ and $I B_{t}^{F}$, and interest rates $R_{t}^{I B, H}$ and $R_{t}^{I B, F}$ to maximize their expected real net worth. The banks pay a fraction (1- $\gamma)$ of their profits as a dividend, with the remaining surplus retained as internal equity finance. Substituting in the expression for $\bar{\omega}_{t+1}$, the problem is written as

11 A common view is that heightened country-specific costs were due to the reassessment of the risk of cross-border lending, particular to stressed economies, occurring in the presence of imperfect information in relation to growth potential and the future profitability of destination banks, and with respect to the possible implications of the heightened sovereign risk (see Al-Eyd and Berkmen 2013; IMF 2013). The linear representation is a parsimonious way to capture the impact of heightened uncertainty on borrowing costs. We have tried other functional forms with a limited impact on the results.

12 As a reminder of notation, note that for most variables, an asterisk indicates the foreign country variables. For the variables corresponding to cross-border flows, the distinction is less clear. $R_{t}^{I B, F^{*}}$ and $R_{t}^{I B, H^{*}}$ are the rates paid by foreign lending backs for foreign and home credit $I B_{t}^{F^{*}}$ and $I B_{t}^{H^{*}}$. The participation constraint (2.30) is for home savings banks so is discounted with the home stochastic discount factor, but depends on the financial positions of foreign-based lending banks. 


$$
\max _{X_{t}} \mathbb{E}_{t}\left[\frac{\Lambda_{t, t+1}}{P_{t+1}^{C}} \gamma\left[1-G\left(\bar{\omega}_{t+1}\right)-\left(1-F\left(\bar{\omega}_{t+1}\right)\right) \bar{\omega}_{t+1}\right] R_{t+1}^{C R} C R_{t}\right],
$$

where $X_{t}=\left\{C R_{t}, I B_{t}^{H}, I B_{t}^{F}, R_{t}^{I B, H}, R_{t}^{I B, F}\right\}$ is a vector of controls, dropping the individual bank index. The maximization is subject to the bank balance sheet equation (2.21), the interbank demand equations (2.22) and (2.23), the composite interest rate (2.24), the loan-to-value equation (2.26), and the saver bank participation constraints given in equations (2.28) and (2.30).

The solution to the contract problem yields a condition that determines the wedge between the nominal risk-free rate $R_{t}^{S}$ and the expected return from credit to the non-financial sector $R_{t+1}^{C R}$. We can express this as

$$
\mathbb{E}_{t}\left[\frac{R_{t+1}^{C R}}{R_{t}^{S}}\right]=\mathbb{E}_{t}\left[s\left(R_{t}^{S}, R_{t}^{I B, H}, R_{t}^{I B, F}, \Gamma_{I B, t}^{\star}, \frac{I B_{t}}{C R_{t}}, \bar{\omega}_{t+1}, \sigma_{\omega, t+1}\right)\right]
$$

with key arguments given, although the nominal stochastic discount factors of both countries are also arguments of function $s$. In this solution, which is given in full in the online appendix, the expected real return to lending is equated with the real marginal cost of external finance. Because the solution is a function of the leverage rather than the bank size, the contract interest rates will be independent of the bank's own history of shocks. As leverage increases, the capital-asset ratio $\frac{N_{t}}{C R_{t}}$ falls, the probability of default increases, and the marginal cost of borrowing rises. This is the financial accelerator mechanism; if, for instance, an adverse shock reduces the net worth of the banking sector, bank leverage will increase, and so will the credit wedge $s$, causing a further deepening of the downturn.

\subsubsection{Firm and Household Credit}

As discussed previously, firm loans are treated as equivalent to equity, and so the return on firm credit is simply the gross return on capital, $R_{t}^{K}$, defined in equation (2.7). The repayment rate on household credit is the contracted nominal rate $R_{t-1}^{M}$. In addition to the amount of total credit extended determined by the solution to equation (2.31), the lending bank chooses to allocate credit to mortgages and business loans to solve

$$
\max _{C R_{t}^{H H}, C R_{t}^{B}} \mathbb{E}_{t} \sum_{s=0}^{\infty} \frac{\Lambda_{t, t+s}}{P_{t+s}^{C}}\left(R_{t+s}^{M}(1-\lambda) C R_{t+s}^{H H}+R_{t+s+1}^{K} C R_{t+s}^{B}\right),
$$

subject to $C R_{t}=(1-\lambda) C R_{t}^{H H}+C R_{t}^{B}$ and where $C R_{t}^{B}=Q_{t}^{K} K_{t}$. The solution implies that 


$$
\mathbb{E}_{t}\left[\frac{\Lambda_{t, t+1}}{P_{t+1}^{C}} R_{t+1}^{C R}\right]=\mathbb{E}_{t}\left[\frac{\Lambda_{t, t+1}}{P_{t+1}^{C}} R_{t}^{M}\right]=\mathbb{E}_{t}\left[\frac{\Lambda_{t, t+1}}{P_{t+1}^{C}} R_{t+1}^{K}\right]
$$

must hold in equilibrium.

\subsection{Monetary Policy}

The monetary authority sets the nominal short-term interest rate in response to deviations of the consumer price inflation rate from the union-wide inflation target $\bar{\Pi}^{E M U}$ and off-trend output growth

$$
R_{t}=\left[\bar{R}\left(\frac{\Pi_{t}^{E M U}}{\bar{\Pi}^{E M U}}\right)^{\varphi^{\pi}}\left(\frac{Y_{t}^{E M U}}{Y_{t-1}^{E M U}}\right)^{\varphi^{y}}\right]^{1-\varphi^{r}} R_{t-1}^{\varphi^{r}} \exp \left(\varepsilon_{t}^{m}\right)
$$

with weights $\varphi^{\pi}$ and $\varphi^{y}$ attached to inflation and output growth respectively. There is inertia in the rule governed by $\varphi^{r}$. The union-wide variables $\Pi_{t}^{E M U}$ and $Y_{t}^{E M U}$ are weighted averages of the home and foreign country variables:

$$
\begin{gathered}
\Pi_{t}^{E M U}=\frac{P_{t}^{E M U}}{P_{t-1}^{E M U}}=\frac{\left(P_{t}^{C}\right)^{n}\left(P_{t}^{C^{\star}}\right)^{1-n}}{\left(P_{t-1}^{C}\right)^{n}\left(P_{t-1}^{C^{*}}\right)^{1-n}} \\
Y_{t}^{E M U}=\left(Y_{t}\right)^{n}\left(Y_{t}^{\star}\right)^{1-n} .
\end{gathered}
$$

With a single policy rate, the economy as presented to this point features a unit root stemming from a single savings rate across both economies. As savers in both countries face the same return on assets, long-run effects from transitory shocks would prevail. For instance, if one of the economies were to draw a positive supply shock, its net foreign asset position would improve and the economy will have a current account surplus that would persist in the long run, with a permanent increase in the wealth of savers. To restore the stationary property of the model, we assume, consistent with past modeling practice in open-economy models, that the central bank applies a small premium on the refinancing rate that depends on the net foreign asset position $N F A_{t}$ of the home country. ${ }^{13}$ The rates paid on central bank credit $C B_{t}$ are determined by

$$
R_{t}=R_{t}^{P}-\vartheta_{t}\left(\exp \left[\kappa \frac{N F A_{t}}{P_{t}^{Y} Y_{t}}\right]-1\right)
$$

13 See Schmitt-Grohe and Uribe (2003) for a full discussion of the techniques used to remove the random walk in open-economy models. 
where $\vartheta_{t}$ is a stationary mean one shock to the premium, and $\kappa$ the premium elasticity. $R_{t}^{P}=R_{t}^{P \star}$ is the central policy rate, and $R_{t}$ and $R_{t}^{\star}$ the rates paid on central bank credit.

Central bank funds are in zero net supply, so if savings banks in the home country borrow from the central bank, it follows that foreign country savings banks are depositors, and $R_{t}>R_{t}^{*}$. The risk premium will cause the net foreign asset position of banks in each country to adjust until $N F A_{t}=N F A_{t}^{\star}=0$ and $R_{t}=R_{t}^{\star}$. The structure of the premium implies that there will be small positive profits in equilibrium which are transferred equally to savers in the union. In the numerical simulations, we choose $\kappa$ sufficiently low to allow the rates to be very close, generating persistent effects of shocks while ensuring that the model is stationary.

\subsection{Market Clearing Conditions}

In each economy, the labor market is in equilibrium when total supply by households equals the demand from intermediate good producers

$$
L_{t}^{D}=\lambda L_{t}+(1-\lambda) L_{t}^{B} .
$$

The corresponding domestic capital market equilibrium condition is given by

$$
K_{t}^{D}=K_{t}
$$

Total demand for domestically produced goods include the demand from domestic households $H_{t}^{T}=\lambda H_{t}+(1-\lambda) H_{t}^{B}$, demand from foreign consumers $X_{t}^{T}=\lambda X_{t}+(1-\lambda) X_{t}^{B}$, demand from capital producers $I_{t}^{K}\left(1-\zeta^{K}\left(I_{t}^{K} / I_{t-1}^{K}-1\right)^{2}\right)$ and from housing good producers $I_{t}^{D}\left(1-\zeta^{D}\left(I_{t}^{D} / I_{t-1}^{D}-1\right)^{2}\right)$ which are net the adjustment costs, and demand by the government, which is given as a proportion $g_{t}$ of output $Y_{t}$. The implied real resource constraint is then

$$
Y_{t}=H_{t}^{T}+X_{t}^{T}+I_{t}^{K}+I_{t}^{D}+g_{t} Y_{t}
$$

with $g_{t}$ following a stationary stochastic process. The net foreign asset position evolves according to the following nominal law of motion:

$$
I B_{t}^{F^{\star}}-I B_{t}^{F}-C B_{t}=\tilde{R}_{t}^{I B, F^{\star}} I B_{t-1}^{F^{\star}}-R_{t-1} C B_{t-1}-\tilde{R}_{t}^{I B, F} I B_{t-1}^{F}+T B_{t},
$$

where the trade balance is defined as

$$
T B_{t}=P_{t}^{P} X_{t}-P_{t}^{I M} I M_{t}
$$

The bilateral terms of trade are given by 


$$
\operatorname{ToT}_{t}=\frac{P_{t}^{I M}}{P_{t}^{X}}
$$

and, as discussed previously, the central bank funds are in zero net supply worldwide, so

$$
n C B_{t}+(1-n) C B_{t}^{\star}=0
$$

\section{Calibration and Parametrization}

A number of the structural parameters of our model are calibrated with the aim of matching key empirical first moments. Other parameters are based on previous estimates in the literature (see Table 1).

Table 1: Calibration and parametrization of model parameters.

\begin{tabular}{llr}
\hline Parameter & Description & Value \\
\hline$B$ & Patient agent discount factor & 0.995 \\
$\beta^{B}$ & Borrowers discount factor & 0.94 \\
$P$ & Utility weight of non-durable consumption & 0.82 \\
$\tau^{C}$ & Home-bias in consumption & 0.75 \\
$\Sigma$ & Elasticity of substitution across consumption varieties & 3.86 \\
$\sigma_{\omega}$ & Standard deviation of loan return shock & 0.0339 \\
$\gamma$ & Retained share of bank profits & 0.947 \\
$T^{B}$ & Home-bias in interbank borrowing & 0.75 \\
$g$ & Steady-state G/Y & 0.2 \\
$\lambda$ & Fraction of savers & 0.65 \\
$\epsilon_{C}$ & Habits formation & 0.564 \\
$\phi$ & Inverse Frisch elasticity & 0.4 \\
$\theta_{C}$ & Elasticity between domestic goods/imports & 1.9 \\
$\alpha$ & Capital share of production & 0.3 \\
$\delta^{K}$ & Capital depreciation rate & 0.025 \\
$\delta^{D}$ & Housing depreciation rate & 0.025 \\
$\zeta^{K}$ & Capital adjustment parameter & 5.2 \\
$\zeta^{D}$ & Housing adjustment parameter & 1.75 \\
$\equiv$ & Calvo parameter & 0.9 \\
$M$ & Monitoring costs & 0.2 \\
$M$ & Borrowers LTV ratio & 0.55 \\
$\theta_{I B}$ & Elasticity of substitution between domestic/cross-border interbank credit & 2 \\
$\zeta_{\sigma}$ & Cross-border interbank cost coefficient & 0.01 \\
$\varphi^{y}$ & Taylor rule response to output growth & 0.15 \\
$\varphi^{\pi}$ & Taylor rule response to inflation & 1.9 \\
$\varphi^{r}$ & Taylor rule persistence & 0.87 \\
$\bar{\Pi}$ & Inflation target & 1.005 \\
\hline & &
\end{tabular}


On the household side, we fix the fraction of savers $\lambda$ in each economy to 0.65 , close to the estimate obtained by Quint and Rabanal (2014). The annualized inflation target is set to $2 \%$, and the discount factor of savers (borrowers) $\beta\left(\beta^{B}\right)$ is chosen to be 0.995 (0.94), ensuring a nominal steady-state annual return on riskfree savings of around 4\%. External habit in consumption $\kappa$ is set at 0.564 according to estimates of Christoffel, Coenen, and Warne (2008) for the euro area. The relative share of non-durables in consumption $\varrho$ is calibrated to be 0.82 to target the output share of housing investment. The inverse of the Frisch labor supply elasticity $\phi$ is parametrized to be 0.4 (cf. Quint and Rabanal 2014). The quasi-share of domestic goods in total consumption $\tau^{C}$ is fixed at 0.75 to ensure a steady-state share of imports in consumption of $25 \%$. The elasticity of substitution between domestic goods and imports $\theta^{C}$ is set at 1.9 in line with Quint and Rabanal (2014) estimates.

On the production side, we choose a value of 0.3 for the share of labor $\alpha$ in the Cobb-Douglas production function. Capital depreciation $\delta_{K}$ and housing depreciation $\delta_{D}$ are assumed to be $10 \%$ per annum. Adjustment costs $\zeta^{K}$ in capital investment are fixed at 5.2 (following estimations in Christoffel, Coenen, and Warne 2008), while those in housing investment $\left(\zeta^{D}\right)$ are set at 1.7 as estimated in Quint and Rabanal (2014). The elasticity of substitution across the final goods $\sigma$ is chosen so as to ensure a steady-state mark-up of 1.35 and the Calvo parameter $\xi$ is set to be 0.9, both in line with estimates obtained by Christoffel, Coenen, and Warne (2008).

On the banking side, savings banks' monitoring costs, $\mu$, are assumed to be 0.2 as in Quint and Rabanal (2014) and Carlstrom and Fuerst (1997). For the borrowers' loan-to-value ratio, we use the estimated value of $m=0.55$ from Iacoviello (2005). The steady-state standard deviation of the loan return shock, $\sigma_{\omega}$, and the bank dividend payment rate, $1-\gamma$, are calibrated to 3.39 percentage points and $4.53 \%$ respectively to target a steady-state value of the loan-to-value ratio of banks $\bar{\omega}$ of 0.9 , in line with typical industry leverage ratios. The default rate of banks is calibrated to be around $0.4 \%$ in steady state, matching the average historical default rate in the banking industry over the period 1970-2010, as well as an equilibrium spread for mortgage and interbank loans of around 1.72 percentage points and 10 basis points respectively over the policy rate, in line with typical measures of the average spreads (see e.g., ECB 2009b). The share of cross-border intra-euro area interbank borrowing $\tau^{I B}$ is set at 0.75 to match figures reported by Colangelo and Lenza (2013). The elasticity of substitution between domestic and foreign interbank funding $\theta^{I B}$ is fixed at 2, implying that these sources of funding are not perfect substitutes. This follows Poutineau and Vermandel (2015) who estimate the substitutability of cross-border corporate loans between the eurozone core and periphery countries. The cross-border interbank cost parameter, $\zeta_{\sigma}$, we set 
Table 2: Parametrization of shock parameters.

\begin{tabular}{llr}
\hline Parameter & Description & Value \\
\hline$\sigma_{A}$ & Technology shock & 0.0126 \\
$\sigma_{G}$ & Government spending shock & 0.00325 \\
$\sigma_{I B}$ & Interbank cost shock & 0.2 \\
$\sigma_{\sigma}$ & Risk shock & 0.00339 \\
$\sigma_{M}$ & Monetary policy shock & 0.00115 \\
$\rho_{A}$ & Technology shock & 0.9 \\
$\rho_{G}$ & Government spending shock & 0.95 \\
$\rho_{I B}$ & Interbank cost shock & 0.8 \\
$\rho_{\sigma}$ & Risk shock & 0.85 \\
\hline
\end{tabular}

to 0.01. For a 1-standard deviation risk shock, ceterus paribus, bank default would increase from 0.1 to $0.25 \%$, implying a rise in the cost, $\Gamma_{I B, t}$, of $0.1 \%$.

On the policy side, we fix the share of government spending in GDP at $20 \%$. Together with the other parametrization of our model, this ensures that we are able to get close matches of the relative spending shares of consumption (59\%), investment (21\%) and housing investment (4.5\%) in GDP with their empirical first moments for the euro area as a whole. Regarding monetary policy, we follow Christoffel, Coenen, and Warne (2008) and set the central bank response to inflation $\varphi^{\pi}$ to 1.9 and to output growth $\varphi^{y}$ to 0.15 . Policy inertia is set at 0.87 .

Finally, the standard deviations and persistence coefficients of the shock processes are largely taken from Christoffel, Coenen, and Warne (2008), with the exception of the risk shock, which is taken from Quint and Rabanal (2014), and the government spending shock, which has been calibrated on the basis of estimates obtained by Smets and Wouters (2003). For the interbank risk premium shock, for which no estimates in the literature are available, we assume a persistence of 0.8 and a standard deviation of 0.2. These are shown in Table 2 .

\section{Numerical Results and Analysis}

To evaluate the model dynamics, we compute a second-order Taylor approximation of the decision and transition functions and simulate impulse response functions ${ }^{14}$. In a first step, we look at the implication of our interbank market setup

14 We used the dynare package to compute simulations (see Adjemian et al. 2011). 
for the transmission of monetary policy by considering a standard monetary policy shock. In a second step, we analyze how frictions in the cross-border interbank market may affect the dynamics of the economy in the face of country-specific idiosyncratic shocks.

\subsection{The Interbank Market and the Transmission of Monetary Policy}

Figure 1 shows the impulse responses of a number of variables to a reduction in the union-wide policy rate and compares these to a modified version of our model in which the interbank frictions are shut off, that is, the model collapses to one of complete financial markets where the spread between bank lending rates and the policy rate is fixed to its steady-state value.
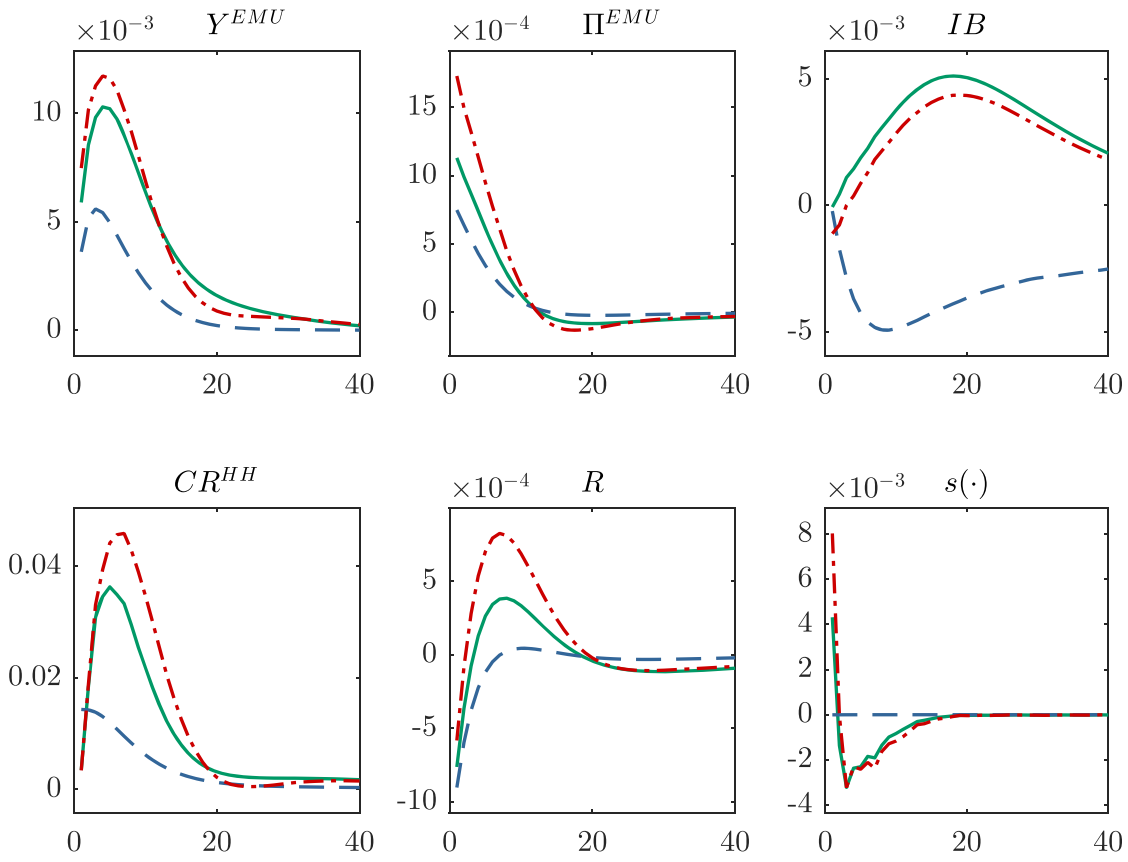

Baseline -- Fixed spreads $-\cdot-\cdot$ Fewer Savers $(\lambda=0.5)$

Figure 1: Impulse response functions to a negative monetary policy shock. $s(\cdot)$ is the external finance premium. Relative deviations from the stochastic steady state except rates, which are in levels. 
In both instances, the interest rate controlled by the monetary authority drops by about the same amount initially. In our baseline model, however, the unanticipated reduction in interest rates leads to an increase in the value of collateral held by lending banks. This, in turn, lowers their funding costs in the interbank market as the perceived risk of default falls. Lending banks operating under perfect competition will pass through the relief in funding costs to their final customers, causing mortgage rates and financing costs faced by non-financial firms to drop by more than the initial reduction in the key policy rate.

It is this additional fall in the borrowing conditions of households and firms that then leads to more investment, more housing demand and, ultimately, higher domestic demand and inflation in the currency union. In other words, like in Bernanke, Gertler, and Gilchrist (1999), the transmission of a conventional change in monetary policy is more powerful in affecting broader macroeconomic conditions. However, unlike in Bernanke, Gertler, and Gilchrist (1999), the amplification in transmission comes directly from banks operating in an interbank market characterized by uncertainty on the part of savings banks when extending shortterm credit to counterparties in need of liquidity.

This implies that there are major differences to a situation where the financial accelerator operates directly at the balance sheet of firms. The impact on aggregate demand, as well as the strength of the pass-through of interbank conditions to final borrowing conditions, will ultimately depend on three factors: the relative share of saver and borrower households in the economy, the structure of lending banks' balance sheets and the degree of competition in the lending market. Starting with the latter, the less concentrated the lending market is, the stronger is the pass through and the more pronounced are the effects on the real economy. That is, modifications of our model along the lines of Gerali et al. (2010), introducing monopolistic competition in the banking sector, can be expected to dampen the accelerator effect as banks would pass on lower interbank funding costs at a pace slower than under our baseline model. Similarly, the larger the share of bank lending to households, the larger the impact on output, given the role played by private consumption in aggregate demand. And, finally, although the friction lowers borrowing costs for firms and impatient households, Figure 1 also shows that the policymaker keeps the interest rate higher relative to the fixed spread economy due to increased output and inflation. Saver households hence face a higher savings rate, causing them to consume less non-durable and durable goods in response. This effect offsets, to some extent, the increase in housing investment coming from borrowers.

We illustrate this last point in 1: the red dashed line shows our baseline model, assuming, however, a smaller share of savers $\lambda=0.5$. As expected, because the financial friction reduces borrowing costs beyond the initial change in the policy 
rate, the more borrowers there are, the larger the accelerator effect. Fewer savers, in turn, imply that the offset from a higher policy, and hence savings rate, will also be smaller.

Overall, therefore, our simulations tend to suggest that, contrary to previous findings in the literature (e.g., Hilberg and Hollmayr, 2011), the presence of an interbank market can, and in many circumstances is very likely to, amplify changes in the key policy rate. And although the mechanism is similar to the wellknown financial accelerator, there are noticeable differences in the way our model setup can give rise to changes in the transmission of monetary policy.

\subsection{Asymmetric Shocks and Cross-Country Spillovers}

A key result of the previous section is that union-wide shocks will propagate differently through the economy once financial frictions are allowed for and that it matters whether these frictions are operating on the banking or the firm side. In this section we will focus on the implications of our interbank market setup for the propagation and impact of idiosyncratic country-specific shocks. Specifically, we look at how a positive shock to the variance of the idiosyncratic loan return shock $\omega(b)$ will affect the behavior of banks in the cross-border interbank market and analyze the footprint this will ultimately leave on aggregate demand.

Recall that savings banks incur additional monitoring costs when taking positions in the cross-border interbank market. These costs are a function of the prevailing level of "economic" risk (cf. equation (2.29)). Therefore, a shock that raises the skewness of the distribution of $\omega(b)$ in one country but not in the other, and hence increases the relative risk of bank default, will cause savings banks to raise the risk premium they charge to borrowers resident in the economy hit by the shock, even though the average loan return remains unchanged.

This can be seen in Figure 2: in our baseline model the funding rate in the cross-border interbank market, $R_{t}^{I B, F}$, increases by significantly more than compared to a model in which banks are insensitive to both macroeconomic and counterparty risks. ${ }^{15}$ As a result, banks with a liquidity deficit will partly substitute more expensive foreign borrowing with domestic borrowing, forcing consumers to

15 To gain a sense of the magnitude of these deviations, note that the shock is scaled such that the annualized probability of bank default increases by about $4 \%$ in the baseline model. This is close to the observed increase in the expected default frequency of financial sector in the euro area in 2012 (see section 3.10 in European Central Bank 2020). Output in the home country falls by around $0.5 \%$, and less than $0.1 \%$ in the foreign economy. In the data, real GDP in Spain and Italy fell by around 3\% year-on-year in 2012, while in contrast, France and Germany experienced only a slowdown. 
dial back more vigorously their imports in response. Naturally, this effect will be stronger the more heavily the economy's banking sector relies on cross-border interbank market funding, $\left(1-\tau^{I B}\right)$, or, similarly, the more difficult it is to switch foreign with domestic funding $\left(\theta_{I B}\right)$. This also means that, should countries differ in their financial structure, symmetric shocks too can cause differences in banks' funding costs across the currency union. For example, an economy which predominantly finances loans to firms and households using funds from abroad will see its overall funding costs increase more sharply in the face of an adverse shock, thereby causing a steeper economic contraction than compared to an economy that mainly relies on domestic funding. This stylized finding has been one of the key aspects of the crisis in peripheral euro area economies: because many banks funded large parts of their liquidity needs abroad, the sudden market freeze meant that aggregate imports fell drastically, thereby reinforcing the macroeconomic fallout caused by the collapse in domestic demand and the rise in funding costs.

Cross-border monitoring costs are, however, only an amplifier of a natural response of our modeling choice. As can be seen in Figure 2, banks resident in the foreign economy would have increased their cross-border interbank rates even in the absence of these costs and despite a measurable reduction in the union-wide monetary policy rate. The reason has to do with the built-in increase in the risk of bank default: with output contracting in response to the shock, domestic banks' leverage rises, causing foreign banks to increase their lending rates.

What is more, with lending to the real economy having become riskier in the wake of the shock, domestic savings banks too will ration their supply of interbank funds and will increase the rate they charge on the remaining funds, causing a contraction in credit supply to the real economy. The consequences are wellknown: with credit less abundant and more expensive, both households and firms reduce their investment and housing activities, amplifying the contraction in aggregate demand that would have prevailed in the absence of frictions in the interbank market.

The consequence is that interbank markets characterized by risky lending and costly state verification have the potential to render monetary policy less effective by contributing to the fragmentation of trades across borders, something that has become evident in the euro area during and after the sovereign debt crisis. At that time, the transmission of the ECB's monetary policy to banks in the periphery had become severely impaired: although it cut its main refinancing rate by 85 basis points between July 2012 and June 2014, bank lending rates to firms in Spain, for example, fell only by some 20 basis points over the same period, reflecting, in part, effective credit rationing in the (cross-border) interbank market. In response to these impairments, the ECB, starting in June 2014, decided on a number of non- 

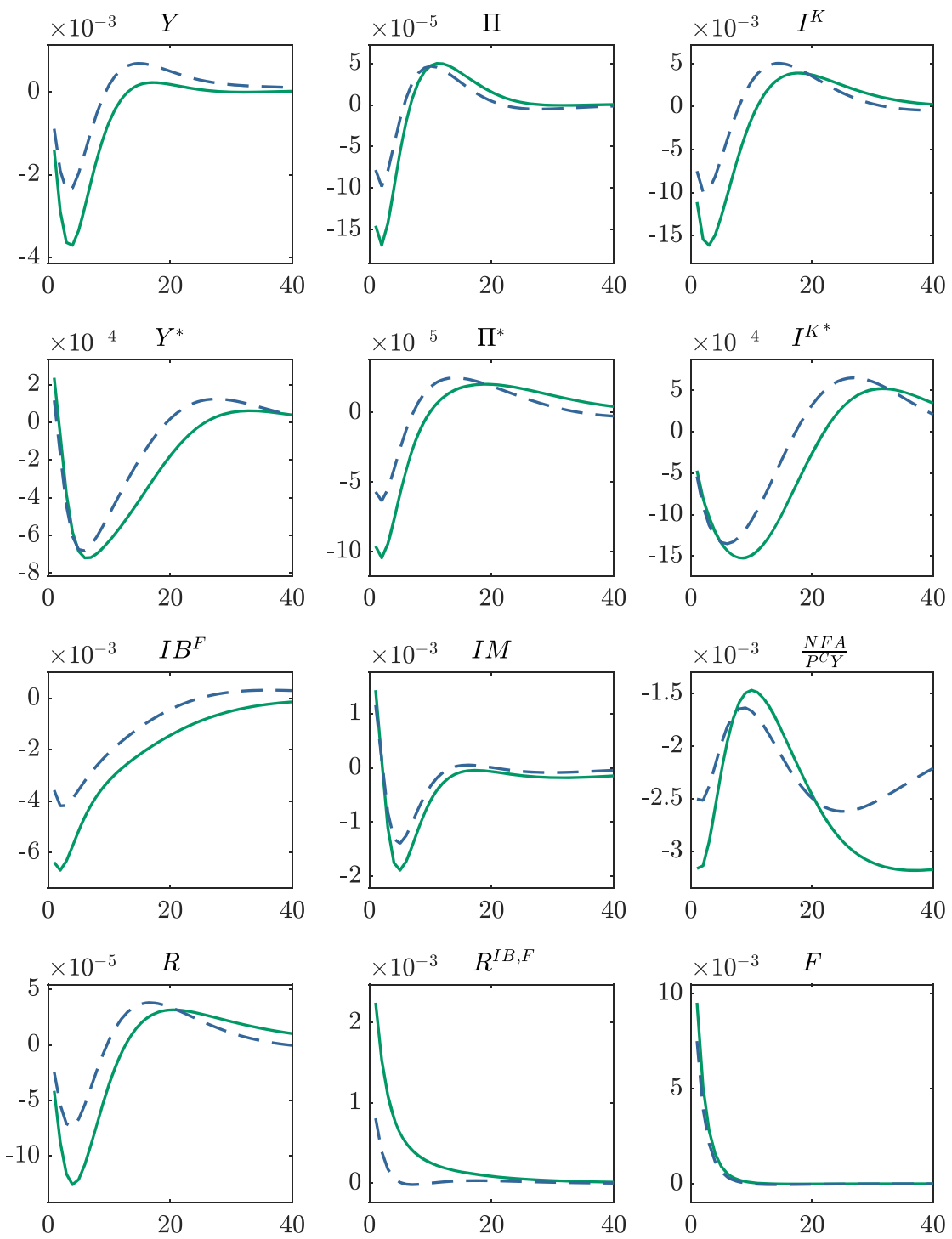

\section{Baseline --- No IB Cost}

Figure 2: Impulse response functions to a transitory risk shock in the home country, comparing baseline model with a version with $\zeta_{\sigma}=0$. Relative deviations from the stochastic steady state except rates and relative NFA, $N F A / P^{C} Y$, and the probability of bank default, $F$, which are in levels. 
standard measures that aimed at restoring the transmission of monetary policy. Some of these measures are the subject of our analysis in the next section.

\section{The Effects of Unconventional Monetary Policy}

In this final section we ask whether recent non-standard monetary policy measures have been able to overcome, or mitigate, frictions in the interbank market. The two policies we discuss are long-term central bank refinancing operations and asset purchases.

\subsection{Long-Term Refinancing Operations}

In our model economy, savings banks have access to funding from the central bank (cf. Section 2.3.2). In addition to standard one-period loans to banks, in this policy exercise, the operations of the central bank may take the form of multi-period loan contracts, similar to the ECB's LTROs ${ }^{16}$. To prevent corner solutions whereby savings banks will choose only short-term or only long-term funding, the central bank sets a single target policy rate on multi-period bonds and allows the shortterm rate to be set via the zero-arbitrage condition. As discussed in Section 2.3.2, the short-term central bank funds will be in zero net supply union-wide. This is also the case with long-term funds. Indeed, in equilibrium, we will find that savings banks will not hold long-term bonds at all; the availability of these loans is sufficient to introduce a wedge between the policy rate on long-term refinance operations and the household saving rate.

To maintain tractability and keep the number of state variables manageable, we follow Rudebusch and Swanson (2012) ${ }^{17}$ and introduce multi-period loan contracts using geometrically decaying repayments over an infinite horizon. This setup reflects the aggregation of a large number of loans at different points of repayment and of different maturities. As well as introducing just one new state variable rather than potentially very many with long maturities, the appeal is that using infinitely long loans with geometrically declining repayments allows us to control the average maturity $\psi \in[0,1)$ with just one parameter, nesting the possibility of $\psi=0$, in which case it collapses to a standard one-period loan contract.

16 See e.g., https://www.ecb.europa.eu/press/pr/date/2011/html/pr111208_1.en.html for information on this policy.

17 Described in detail to analyze term premia on bonds in a working paper version of the article (see Rudebusch and Swanson 2008). Used to introduce multi-period loan contracts in Benes and Lees (2010). 
Every period $t$, a savings bank can take out a new loan $C B_{t}$ and agree to repay an infinite number of declining payments such that the total amount due at period $t$ is given by

$$
C B_{t-1}^{T}=\sum_{k=1}^{\infty} \psi^{k-1} R_{t-k}^{L T} C B_{t-k}
$$

When $\psi>0, R_{t}^{L T}$ is no longer equivalent to an interest rate. To analyze the role of the LTRO policy, we assume that the central bank chooses $R_{t}^{L T}$ so that the average interest rate on long-term borrowing equals the policy rate $R_{t}$. As we are using perpetual loan repayments, we measure the average duration using Macaulay's duration of a stream of payments. It is then straightforward to calculate the equivalent average nominal interest rate on the amount borrowed from the total amount repaid. We find this leads to the following relationship between the rate $R_{t}^{L T}$ and the policy rate $R_{t}$ :

$$
R_{t}=\left(\frac{R_{t}^{L T}}{1-\psi}\right)^{(1 / d)}
$$

with average loan duration $d=R /(R-\psi)$, where $R$ is the steady-state policy rate ${ }^{18}$.

We can then express equation (5.1) in recursive form as

$$
C B_{t}^{T}=\psi C B_{t-1}^{T}+R_{t}^{L T} C B_{t} .
$$

The important thing to note is that even if the bank does not borrow from the central bank in equilibrium, as will be the case with purely symmetric shocks, the availability of these loans is sufficient to have an important impact on the household saving rate, a point we will return to later. Using equation 5.3 as a constraint in the profit maximization problem of the savings bank leads to the following first-order conditions:

$$
\begin{aligned}
\phi_{t} & =\mathbb{E}_{t}\left[\frac{\Lambda_{t, t+1}}{\Pi_{t}^{C}}\left(1+\phi_{t+1} \psi\right)\right] \\
\phi_{t} R_{t}^{L T} & =\mathbb{E}_{t}\left[\frac{\Lambda_{t, t+1}}{\Pi_{t}^{C}} R_{t}^{S}\right] .
\end{aligned}
$$

18 For perpetual loan repayments, the average loan duration is measured using Macaulay's duration of a stream of payments, given by $d_{t}=\sum_{t=1}^{\infty} t P V_{t} / \sum_{t=1}^{\infty} P V_{t}$ where $P V_{t}$ is the present value of the cash flow (see e.g., Marrison 2002). Applying this to our example, we find in simulations that $d_{t}$ experiences only tiny fluctuations around its steady-state value, and so we use the steady-state value as a close approximation. This can be simplified to $d=\frac{R}{R-\psi}$. It is then straightforward to calculate the average interest rate given that borrowing is a convergent series. 

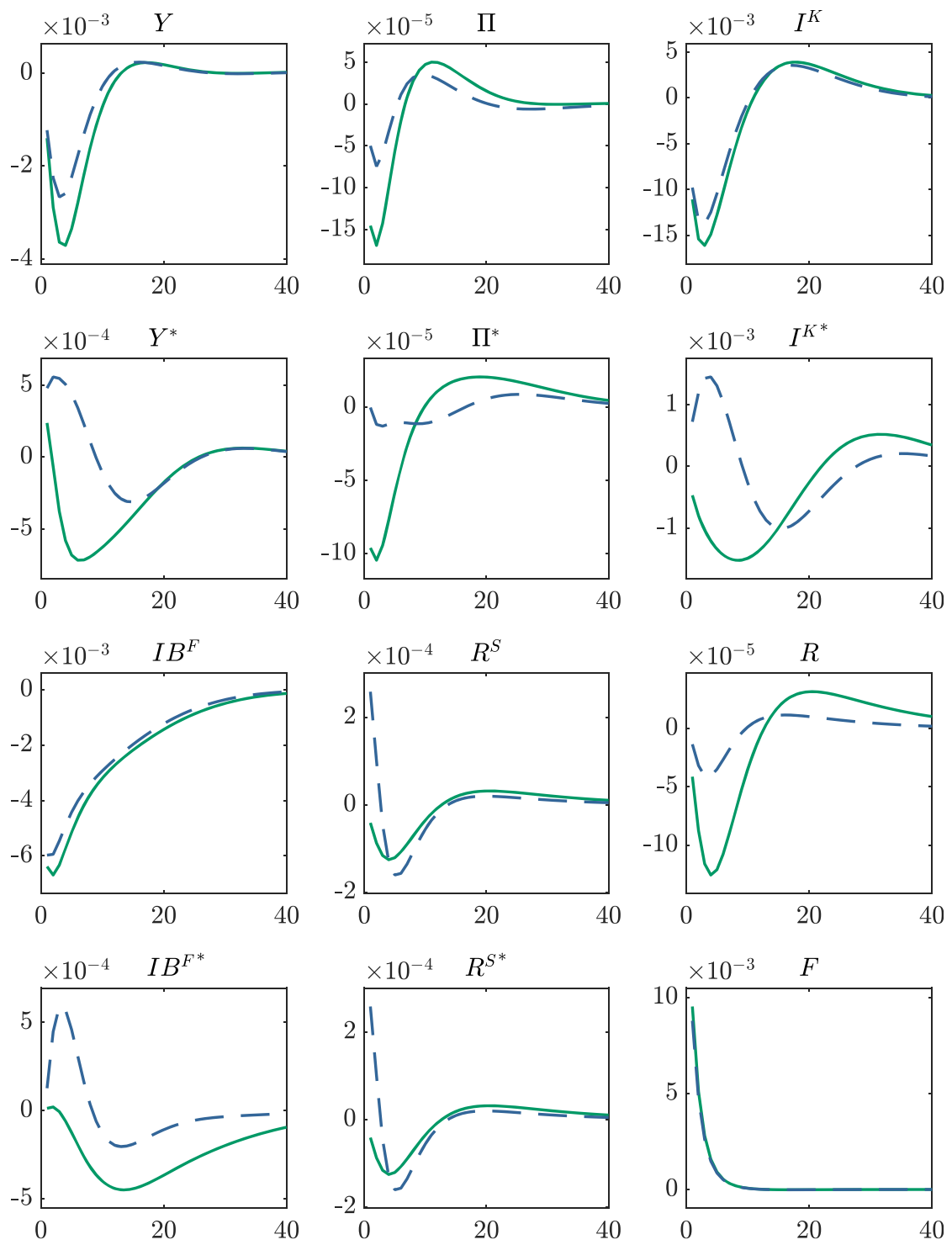

\section{Baseline - - LTRO Policy}

Figure 3: Impulse response functions to a transitory risk shock with central bank with and without LTRO policy response. Relative deviations from the stochastic steady state except rates, which are in levels. 
This, with equation (5.2), gives the spread between the policy rate $R_{t}$ and the deposit rate $R_{t}^{S}$. $\phi_{t}$ is the real present value of the Lagrange multiplier on the law of motion of repayments due and is a nominal pricing kernel for central bank credit. When $d=1$ and $\psi=0$, then $R_{t}^{L T}=R_{t}=R_{t}^{S}$ as in the standard model, and $\phi_{t}$ is just the nominal stochastic discount factor. As the loan duration increases so $\psi>1$, the implied future stream of payments increase and $\psi_{t}>\frac{\Lambda_{t, t+1}}{\Pi_{t, t+1}}{ }^{19}$

Figure 3 shows the LTROs at work, comparing the impulse response functions to the same risk shock analyzed before, once with $d=1$ and once with $d=16^{20}$. This calibration mimics the four-year loan duration of the ECB's targeted LTROs introduced in 2014. The policy has two major effects. First, in the face of an adverse shock, fewer cuts in policy rates are required to achieve the equivalent stimulus in a multi-period loan economy. The reason is that the reduction in policy rates lowers the average rate of interest for a longer period and hence further reduces the effective present funding costs of forward-looking banks. That is, long-term refinancing operations with fixed interest rates, such as the latest series of targeted LTROs, ensure planning certainty for banks and thereby, in practice, provide major help with respect to maturity transformation between longer-term lending and often short-term refinancing. And with banks immediately passing on the additional funding cost relief to the ultimate borrowing conditions of households and firms, policymakers are able to frontload required accommodation and thereby mitigate the economic downturn.

The second interesting feature of LTROs is the asymmetric impact when economies are hit by idiosyncratic shocks. As we argued before, once $d>1\left(\phi_{t}>0\right)$, the deposit rate in each country will no longer be fixed to the policy rate by the zero arbitrage condition. As equations (5.2) and (5.5) highlight, the spread between the policy rate and the deposit rate depends on the Lagrange multiplier, itself a function of the household stochastic discount factor. Specifically, using equations (5.2) and (5.5) we can give the spread as

19 One difficulty with our approach is that introducing the policy, or changing the average duration, during a model simulation would cause the mapping between the repayment rate and the policy rate to be lost. For example, the average loan duration stems from the continued existence of loans with a fixed parameter $\psi$. If $\psi$ were time varying, it would be considerably more difficult to compute the average loan duration or the average rate across the loans. For this reason, we draw a comparison between a model in which the central bank provides standard one-period credit and a long-term refinancing case with $\psi>0$ and duration $d>1$ fixed.

20 This corresponds to an average loan duration $\psi$ of 0.9422 . 


$$
\frac{R_{t}}{R_{t}^{S}}=\frac{\mathbb{E}_{t}\left[\frac{\Lambda_{t, t+1}}{\Pi_{t}^{C}}\right]}{\left[\phi_{t}(1-\psi)\right]^{1 / d}},
$$

where

$$
\phi_{t}=\mathbb{E}_{t}\left[\frac{\Lambda_{t, t+1}}{\Pi_{t}^{C}}\left(1+\phi_{t+1} \psi\right)\right] .
$$

So, asymmetric shocks will affect the spread differently in each country as a firstorder effect. From equations (5.2) and (5.5), a first-order approximation suggests that

$$
\frac{R_{t}^{S}}{\mathbb{E}_{t}\left[1+\phi_{t} \psi\right]}=\frac{R_{t}^{S *}}{\mathbb{E}_{t}\left[1+\phi_{t}^{\star} \psi\right]} .
$$

In other words, if the expected path of the nominal stochastic discount factor is greater in the domestic economy than in the $\mathbb{E}_{t} \phi_{t+1}>\mathbb{E}_{t} \phi_{t+1}^{\star}$ foreign, then it follows that $R_{t}^{S}>R_{t}^{S \star}$, which implies that .

This can be seen in Figure 3. Because consumers in the foreign economy, following the shock, expect a lower future marginal utility of consumption relative to the domestic country, LTROs, by easing financial conditions abroad by more, are able to fully offset any negative spillovers of the original shock to the rest of the currency union. Of course, the extent of the easing can differ from shock to shock, but LTROs can generally be thought of as a powerful stabilization tool in a currency union. This has been confirmed by recent ECB analysis (ECB 2017). They show that from June 2014 to July 2015, i.e., after the first TLTRO operation, non-bidders in vulnerable and non-vulnerable economies reduced their lending rates by about the same amount, while after the second operation, in the period from March to December 2016, the reduction in lending rates was larger in non-vulnerable economies, consistent with the predictions from our model. This emphasizes that the sheer existence of the policy is enough to reduce financing conditions across the currency union and, hence, to help central banks reach their price stability objectives. ${ }^{21}$

\subsection{Asset Purchases}

The second policy instrument we analyze is asset purchases by central banks, which became an integral part of policymakers' toolkit after, and in some

21 We tried different parameter values in the Taylor rule and found the relative impact of the availability of LTROs was unchanged. 
jurisdictions even before, the outbreak of the global financial crisis. Several attempts have been made in the literature to quantify the effects of such purchases ${ }^{22}$. On the theoretical front, Chen, Cúrdia, and Ferrero (2012) and Gertler and Karadi (2013) have recently made useful progress in capturing the effects of asset purchases on the broader macroeconomy. In this paper, we want to focus on one element of the ECB's asset purchase programme that has received less attention in the literature and that is particularly suited to study within the context of our model setup: its ABSPP.

The aim of this programme, launched in November 2014, is to facilitate credit provision to the real economy by freeing up bank balance sheet capacity. Although the effects of securitization are more complex in practice, mainly related to regulation, the general idea behind this programme can be illustrated by assuming that the central bank purchases assets directly from banks. Indeed, one of the main reasons for banks to engage in securitization is balance sheet relief: securitization typically involves a true sale of the underlying asset to a special purpose vehicle, removing assets from the balance sheet and thereby reducing the amount of capital that a financial institution is required to hold. We therefore follow Gertler and Karadi (2011) and treat asset purchases as if the central bank lends directly to the private sector, which is a convenient shortcut to analyzing the effects of the ECB's ABSPP.

Specifically, the central bank issues one-period bond at the market rate and uses the proceeds to purchase a certain share $\Theta_{t}$ of loans from lending banks. Profits are distributed to the households via lump sum transfers ${ }^{23}$. The central bank budget constraint can be written as

$$
\begin{gathered}
\Theta_{t}\left(C R_{t}^{H H}+C R_{t}^{F}\right)=B_{t}^{C B} \\
T_{t}=R_{t}^{C R} \Theta_{t}\left(C R_{t-1}^{H H}+C R_{t-1}^{F}\right)-R_{t-1}^{S} B_{t-1}^{C B},
\end{gathered}
$$

where $T_{t}$ are transfers to households and $B_{t}^{C B}$ are central bank issued bonds. The first constraint is that all funds raised are used to purchase assets and the second is that all profits are transferred to households.

At the start of the period during which the asset purchase will take place, the policymaker announces the purchase decision. This implies that the lending banks' first-order conditions are unchanged except for the volume of loans on banks' balance sheets, which changes to

22 For the United States see e.g., Krishnamurthy and Vissing-Jorgensen (2011) and Gagnon, Raskin, and Remache (2011); for the euro area see e.g. Blattner and Joyce (2016) and Altavilla, Carboni, and Motto (2015).

23 Likewise, if there are losses, these are borne by households through lump-sum taxes. 

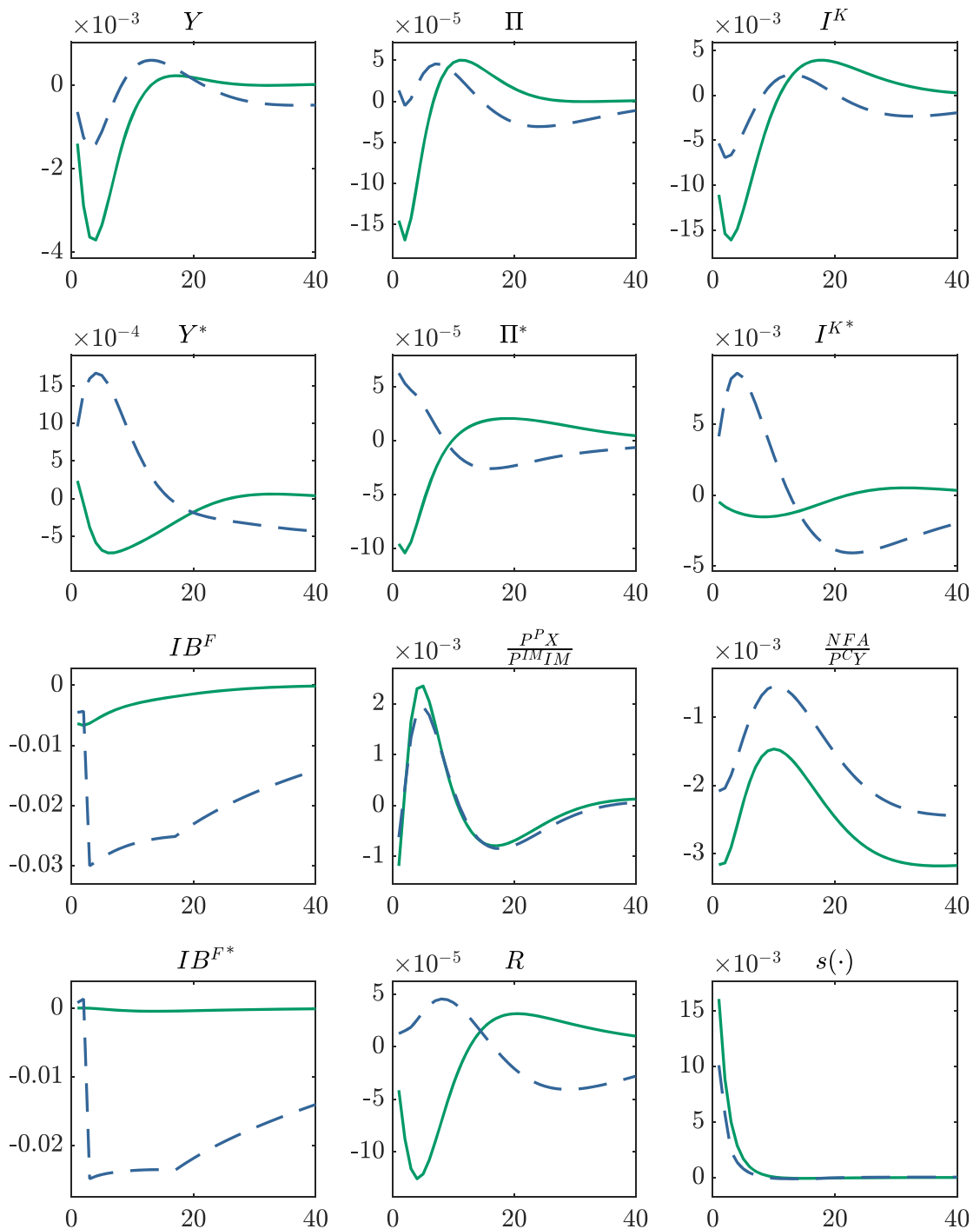

Baseline - - Asset Purchase Policy

Figure 4: Impulse response functions to a transitory risk shock with central bank assetpurchase policy response. Relative deviations from the stochastic steady state except rates, net exports, $P^{P} X / P^{I M} I M$, and relative NFA, NFA $/ P^{C} Y$, which are in levels. 


$$
C R_{t}=\left(1-\Theta_{t}\right)\left(C R_{t}^{H H}+C R_{t}^{F}\right)
$$

With this in mind, we now examine how asset purchases can help stabilize the economy in the face of an adverse shock, using again, for reasons of comparability, a risk shock in the domestic economy. Figure 4 shows the general workings of a temporary asset purchase programme. In our calibration the central bank is assumed to purchase $2 \%$ of all available assets in the first period, in equal proportions across economies, and to hold them for four years. At this point, the assets are gradually resold to the private sector, causing the central bank's balance sheet to contract by $2.5 \%$ every quarter.

The message is unambiguous: asset purchases in the form of loans, either directly or through purchases of ABS, can be an effective substitute, or complement, to reductions in the key policy rate. By reducing banks' risk exposure to the real economy, policymakers are able to lower banks' market-based funding needs and to compress their external finance premium in the interbank market. Lower interbank funding costs, in turn, are passed on to households and firms, which stimulate demand for loans and mortgages and, ultimately, investment and aggregate demand. As can be seen in Figure 4, in our example purchases of loans succeed in effectively mitigating the fall in output and inflation without lowering the key policy rate. This means that, at the effective lower bound, such a policy can be an effective complement to changes in the conventional policy instrument. Note the interbank market lending volumes in Figure 4 mirror the asset purchases; the central bank makes a large purchase in the first period, the assets are held for four years before being gradually resold to the private sector.

Finally, in Figure 5, we perform a comparative analysis of the efficiency of our two unconventional policy instruments to the same transitory risk shock. To ensure broad comparability, both policies are calibrated to ensure the same target horizon of four years. The chart emphasizes that while both policies can effectively mitigate the impact of adverse shocks on output and inflation, asset purchases, even in relatively small size, are likely to be more powerful, reflecting the direct risk transfer from private to public balance sheets. This means there is a trade-off for policymakers between policy effectiveness and risk exposure. While an analysis of the optimal policy use goes beyond the scope of this article, it may seem advisable to central banks to choose the optimal policy mix depending on the severity and persistence of the shock, also bearing in mind that very large adverse shocks may affect the supply side of the economy through hysteresis effects. In these instances, policy may prefer to minimize the initial impact of the shock by choosing a policy that would re-establish quickly orderly trading conditions in interbank markets.

\subsection{Welfare Considerations}

Although the analysis of optimal policy is beyond the scope of this study, it is possible to compare welfare outcomes conditional on the scenarios shown in 

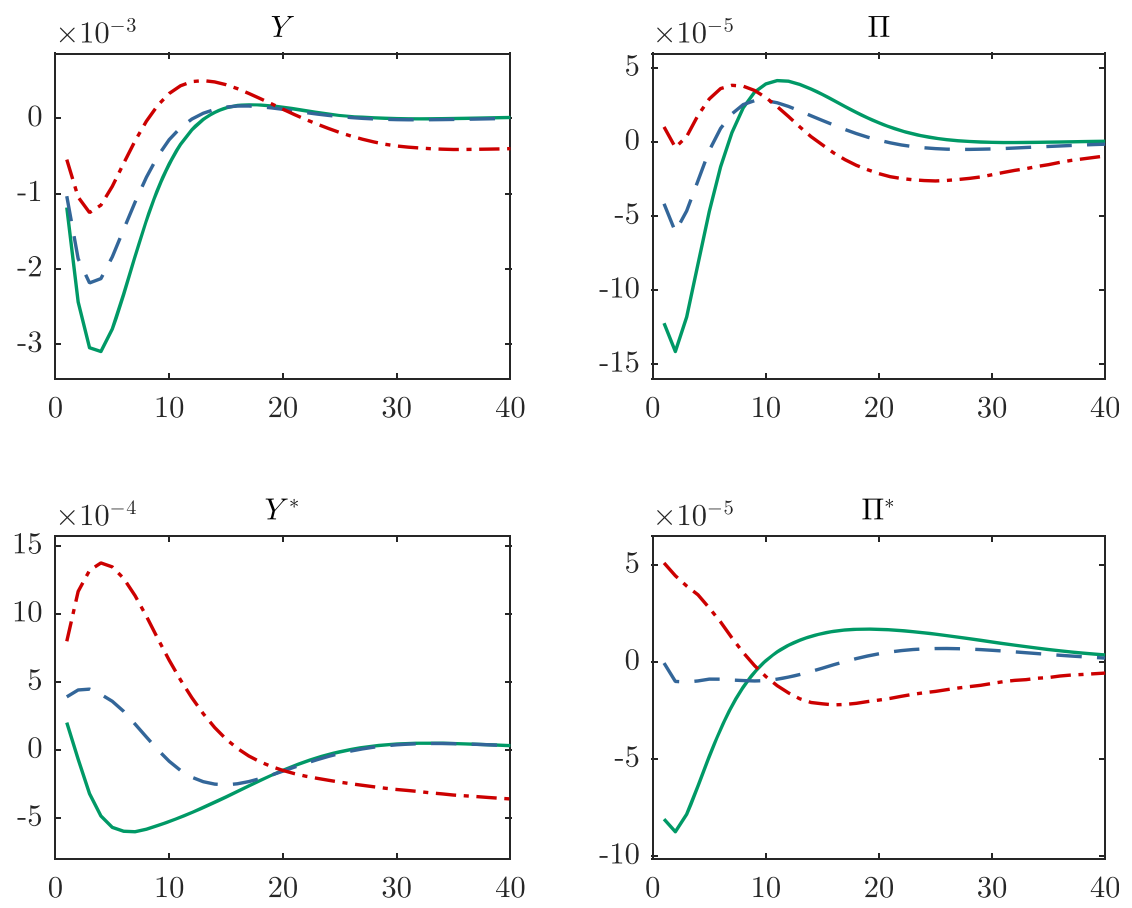

Baseline - - Asset Purchase Policy - - - - LTRO Policy

Figure 5: Impulse response functions to a transitory risk shock comparing central bank assetpurchase policy response and LTROs. $Y$ shows relative deviations from the stochastic steady state and $\Pi$ shows level deviation.

Figure 5. We show the welfare of the alternative policies relative to the baseline model in Figure 6. Welfare for each household is defined as the discounted sum of future utility with total welfare given as the average, weighting households by their population share. The figure gives this in consumption equivalence terms and shows the period-by-period proportion of consumption that all households would give up in order to be under the alternative policy framework ${ }^{24}$. As this is a conditional welfare comparison, to give a value for the effect of a policy programme on welfare we calculate the total value in terms of annual consumption, finding that the asset purchase policy leads to total welfare gains of $2.7 \%$ of a single year of

24 To be a little more specific, each period, we solve $W\left(C_{t}^{\text {baseline }}\left(1+\xi_{t}^{A}\right)\right)=W\left(C_{t}^{A P P}\right)$ and $W\left(C_{t}^{\text {baseline }}\left(1+\xi_{t}^{B}\right)\right)=W\left(C_{t}^{L T R O}\right)$ for $\xi_{t}^{A}$ and $\xi_{t}^{B}$, where $V_{t}(i, j)=U_{t}(i, j)+\beta(i) \mathbb{E}_{t}\left[V_{t+1}(i, j)\right]$ for household of type $i$ in country $i$, and $W$ averages $V(i, j)$ weighting by population share. 


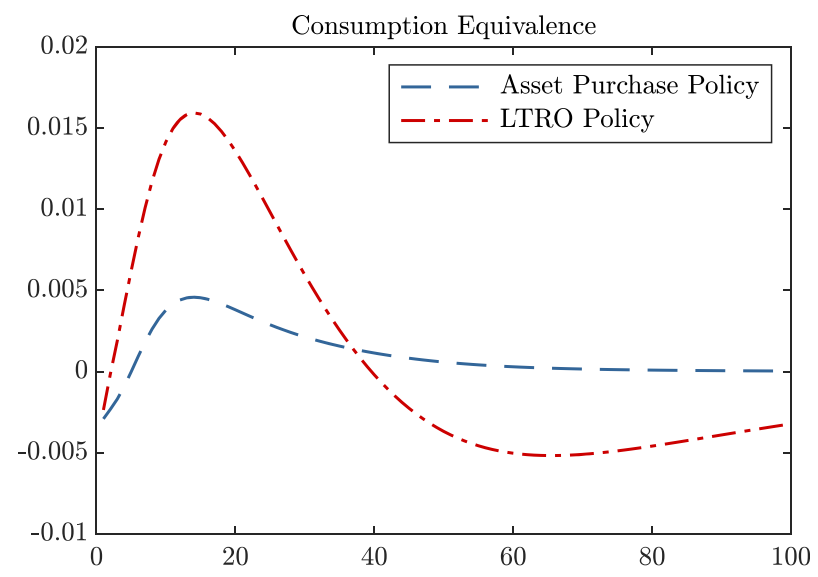

Figure 6: Welfare relative to baseline in period-by-period consumption equivalence terms. Conditional on the impulse responses shown in Figure 5, for each period this shows value of the policy at time $t$ in terms of period $t$ consumption.

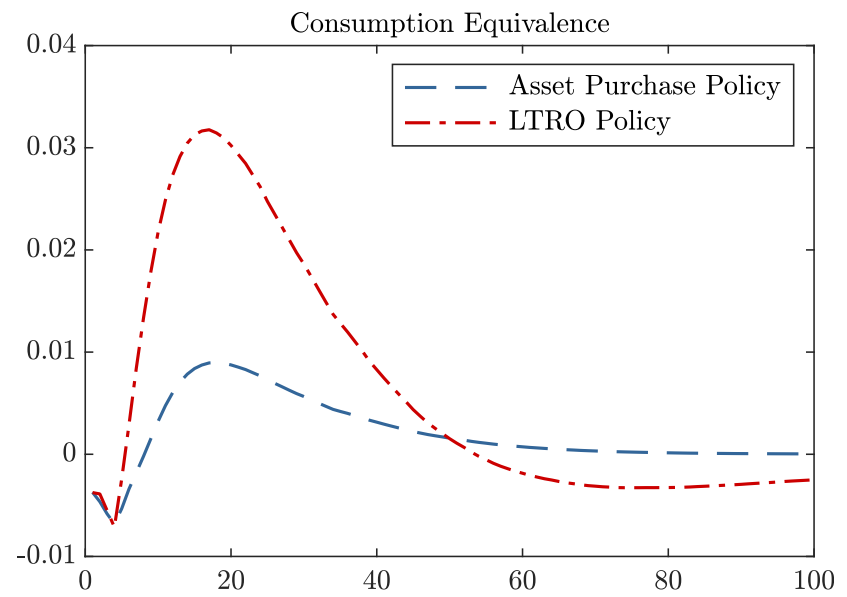

Figure 7: Welfare relative to baseline in period-by-period consumption equivalence terms conditional on a risk shock and interest rates prevented from falling from 4 quarters. For each period this shows value of the policy at time $t$ in terms of period $t$ consumption.

consumption $^{25}$. The LTRO policy, in contrast, in the end leads to welfare losses equivalent to $1.2 \%$ of annual consumption despite offering welfare gains in the short term.

25 The total period-by-period welfare gains add up to $2.7 \%$ of annual steady state consumption. 
This comparison does not give a full picture, as it assumes that the central bank has full freedom to utilize conventional monetary policy. If this were not possible, because of the zero-lower bound on nominal interest rates, for example, then the LTRO policy could be an effective substitute for conventional interest rate adjustments. To illustrate this point, we repeat the exercise, only this time preventing the interest rate from adjusting downward for four periods. The period-byperiod relative welfare for each policy is shown in Figure 7.

This time, the LTRO policy offers total welfare gains equivalent to $5 \%$ of annual consumption over the baseline case, highlighting the value of credibly promising low-for-long interest rates. The asset purchase programme leads to welfare gains equal to $13 \%$ of annual consumption, up from just $2.7 \%$. Although an illustration, the exercise indicates the potential of significant welfare gains from an expanded policy toolkit when conventional policy is constrained.

\section{Conclusion}

Growing levels of excess liquidity in the wake of the ECB's asset purchase programme, together with attractive conditions attached to the ECB's targeted longerterm refinancing operations, have reduced the need of banks to seek funds in the euro area interbank market. Although these measures have undoubtedly contributed to restoring the transmission of monetary policy, and thereby to reinforcing the economic expansion the euro area has been enjoying since about mid-2013, they also mask the prevailing fragilities related to the trading of central bank reserves in a currency union characterized by structural differences across borders. Such differences may lead to persistent cross-border capital flows intermediated, in part, by banks that are likely to price interbank loans not only according to the credit quality of their counterparts, but taking also into account differences in macroeconomic risk across euro area jurisdictions.

This article showed that such frictions in the interbank market may severely constrain the ability of monetary policymakers to achieve their area-wide price stability objective using merely conventional policy instruments. In good times, credit frictions in the interbank market may amplify changes in the key policy rate and contribute to boosting cross-border interbank loans, creating risks of irrational exuberance. In bad times, pro-cyclicality in bank lending and pricing may offset efforts by the central bank to stimulate the economy.

The good news is that the crisis has proven that unconventional policy measures can be highly effective in overcoming frictions in the interbank market. The findings in this article confirm, by and large, this intuition. In particular, long-term refinancing operations as well as asset purchase programmes can complement, or 
substitute for, changes in the key policy rate and ease financial conditions at a time when access to interbank credit might be restricted or excessively expensive. This is especially true when there is restricted room to adjust the policy rates downward due, for example, to the zero-lower bound on nominal interest rates. Limiting the recourse to such facilities in future crises, however, requires a more forceful convergence in the growth capacities of euro area economies, a task that lies beyond central bank mandates.

Acknowledgments: The authors would like to thank Stephan Fahr for all his help on the project. Thanks also to Dominic Quint, Paul Levine, Cristiano Cantore, Raf Wouters, Tiago Cavalcanti and an anonymous referee for helpful suggestions.

Research funding: The paper was based on work written while Jonathan was a doctoral candidate; he gratefully acknowledges the financial support from the Economic and Social Research Council [grant number ES/J500148/1] received during this period.

\section{References}

Abbassi, P., F. Bräuning, F. Fecht, and J.-L. Peydró. 2014. “Cross-border Liquidity, Relationships and Monetary Policy: Evidence from the Euro Area Interbank Crisis." Deutsche Bundesbank, Discussion Paper Series 45/2014.

Adjemian, S., H. Bastanie, F. Karamé, M. Juillard, J. Maih, F. Mihoubi, G. Perendia, J. Pfeifer, M. Ratto, and S. Villemot. 2011. "Dynare: Reference Manual Version 4." 160. Dynare Working Paper Series (1).

Afonso, G., A. Kovner, and A. Schoar. 2011. "Stressed, Not Frozen: The Federal Funds Market in the Financial Crisis." The Journal of Finance 66 (4): 1109-39.

Al-Eyd, A. J., and P. Berkmen. 2013. Fragmentation and Monetary Policy in the Euro Area. Washington D.C: International Monetary Fund, Working Paper 13/208.

Altavilla, C., G. Carboni, and R. Motto. 2015. Asset Purchase Programmes and Financial Markets: Lessons from the Euro Area. Frankfurt am Main: European Central Bank, Working Paper Series, No. 1864.

Armington, P. S. 1969. A Theory of Demand for Products Distinguished by Place of Production. Washington DC: International Monetary Fund, Staff papers, No. 16.

Benes, J., and K. Lees. 2010. Multi-period Fixed-Rate Loans, Housing and Monetary Policy in Small Open Economies. Wellington: Reserve Bank of New Zealand, Discussion Paper Series, DP2010/03.

Bernanke, B. S., M. Gertler, and S. Gilchrist. 1999. "The Financial Accelerator in a Quantitative Business Cycle Framework." In Handbook of Macroeconomics, Vol. 1, edited by J. B. Taylorand M. Woodford, 1341-93. Amsterdam: Elsevier B.V. chapter 21.

Blattner, T. S., and M. A. S. Joyce. 2016. Net Debt Supply Shocks in the Euro Area and the Implications for QE. Frankfurt am Main: European Central Bank, Working Paper Series, No 1957. 
Calvo, G. 1983. "Staggered Prices in a Utility Maximizing Framework." Journal of Monetary Economics 12 (3): 383-98.

Carlstrom, C. T., and T. S. Fuerst. 1997. "Agency Costs, Net Worth, and Business Fluctuations: A Computable General Equilibrium Analysis.” The American Economic Review 87 (5): 893-910.

Carrera, C., and H. Vega. 2012. Interbank Market and Macroprudential Tools in a DSGE Mode. Banco Central de Reserva del Perú, Working Paper Series, No. 2012-014.

Chen, H., V. Cúrdia, and A. Ferrero. 2012. "The Macroeconomic Effects of Large-Scale Asset Purchase Programmes.” The Economic Journal 122 (564): 289-315.

Christensen, I., and A. Dib. 2008. "The Financial Accelerator in an Estimated New Keynesian Model." Review of Economic Dynamics 11: 155-78.

Christiano, L. J., M. Eichenbaum, and C. L. Evans. 2005. "Nominal Rigidities and the Dynamic Effects of a Shock to Monetary Policy." Journal of Political Economy 113 (1): 1-45.

Christiano, L., R. Motto, and M. Rostagno. 2003. The Great Depression and the Friedman-Schwartz Hypothesis. Cambridge, MA: National Bureau of Economic Research, Working Paper Series 6, No. 10255.

Christiano, L., R. Motto, and M. Rostagno. 2010. Financial Factors in Economic Fluctuations. European Central Bank, Working Paper Series, No. 1192.

Christiano, L., R. Motto, and M. Rostagno. 2014. "Risk Shocks.” The American Economic Review 104 (1): 27-65.

Christoffel, K. K., G. Coenen, and A. Warne. 2008. The New Area-wide Model of the Euro Area: A Micro-Founded Open-Economy Model for Forecasting and Policy Analysis. Frankfurt-amMain: European Central Bank, Working Paper Series, No. 944.

Colangelo, A., and M. Lenza. 2013. “Cross-border Banking Transactions in the Euro Area.” In Proceedings of the Sixth IFC Conference on "Statistical Issues and Activities in a Changing Environment”, 28-29 August 2012, 518-31. Basel: Bank for International Settlements.

Cornett, M. M., J. J. McNutt, P. E. Strahan, and H. Tehranian. 2011. "Liquidity Risk Management and Credit Supply in the Financial Crisis.” Journal of Financial Economics 101 (2): 297-312.

Darracq Paries, M., C. K. Sørensen, and D. Rodriguez-Palenzuela. 2011. "Macroeconomic Propagation under Different Regulatory Regimes: Evidence from an Estimated DSGE Model of the Euro Area." International Journal of Central Banking 7 (4): 49-113.

De Andoain, C. G., P. Hoffmann, and S. Manganelli. 2014. "Fragmentation in the Euro Overnight Unsecured Money Market.” Economics Letters 125 (2): 298-302.

De Graeve, F. 2008. "The External Finance Premium and the Macroeconomy: US Post-WWII Evidence." Journal of Economic Dynamics and Control 32 (11): 3415-40.

de Walque, G., O. Pierrard, and A. Rouabah. 2010. "Financial (In)stability, Supervision and Liquidity Injections: A Dynamic General Equilibrium Approach.” The Economic Journal 120 (549): 1234-61.

Demirgüç-Kunt, A., and H. Huizinga. 2010. "Bank Activity and Funding Strategies: The Impact on Risk and Returns." Journal of Financial Economics 98 (3): 626-50.

Dib, A. 2010. Banks, Credit Market Frictions, and Business Cycles. Ottawa: Bank of Canada. Staff Working Papers 10-24.

Dixit, A., and J. E. Stiglitz. 1977. "Monopolistic Competition and Optimum Product Diversity." The American Economic Review 67 (3): 297-308.

Dräger, L., and C. R. Proaño. 2015. Cross-border Banking and Business Cycles in Asymmetric Currency Unions. Hamburg: University of Hamburg, DEP (Socioeconomics)Discussion Papers, Macroeconomics and Finance Series 1/2015. 
European Central Bank. 2009a. Euro Money Market Study 2008, Technical report. Frankfurt am Main: European Central Bank.

European Central Bank. 2009b. Housing Finance in the Euro Area, Structural Issues Report. Frankfurt am Main: European Central Bank.

European Central Bank. 2015. Euro Money Market Study 2014, Technical report. Frankfurt am Main: European Central Bank.

European Central Bank. 2017. Impact of the ECB's Non-standard Measures on Financing Conditions: Taking Stock of Recent Evidence. Frankfurt am Main: Economic Bulletin (2017), Issue 2.

European Central Bank. 2020. ESRB Risk Dashboard, 10 June 2020. Frankfurt-am-Main: European Central Bank and the European Systemic Risk Board.

Flannery, M. J. 1996. "Financial Crises, Payment System Problems, and Discount Window Lending." Journal of Money, Credit, and Banking 28 (4): 804-24.

Freixas, X., and C. Holthausen. 2005. "Interbank Market Integration under Asymmetric Information." Review of Financial Studies 18 (2): 459-90.

Gagnon, J., M. Raskin, and J. Remache. 2011. "The Financial Market Effects of the Federal Reserve's Large-Scale Asset Purchases.” International Journal of Central Banking 7 (1): 3-43.

Gerali, A., S. Neri, L. Sessa, and F. M. Signoretti. 2010. "Credit and Banking in a DGSE Model of the Euro Area.” Journal of Money, Credit, and Banking 42 (6): 107-41.

Gertler, M., and P. Karadi. 2011. “A Model of Unconventional Monetary Policy.” Journal of Monetary Economics 58 (1): 17-34.

Gertler, M., and P. Karadi. 2013. "QE 1 vs. 2 vs. 3...: A Framework for Analyzing Large-Scale Asset Purchases as a Monetary Policy Tool.” International Journal of Central Banking 9 (S1): 5-53.

Gertler, M., and N. Kiyotaki. 2010. "Financial Intermediation and Credit Policy in Business Cycle Analysis." Handbook of Monetary Economics 3 (11): 547-99.

Goodfriend, M., and B. T. Mccallum. 2007. "Banking and Interest Rates in Monetary Policy Analysis: A Quantitative Exploration.” Journal of Monetary Economics 54 (2007): 1480-507.

Hilberg, B., and J. Hollmayr. 2011. Asset Prices, Collateral and Unconventional Monetary Policy in a DSGE Model. Frankfurt-am-Main, Frankfurt: European Central Bank. Working Paper Series, No. 1373.

lacoviello, M. 2005. "House Prices, Borrowing Constraints, and Monetary Policy in the Business Cycle.” The American Economic Review 95 (3): 739-64.

IMF. 2013. European union: Publication of Financial Sector Assessment Program DocumentationTechnical Note on Financial Integration and Fragmentation in the European Union.

Washington D.C: International Monetary Fund. Country report no. 13/71.

in't Veld, Daan, and Iman van Lelyveld. 2014. "Finding the Core: Network Structure in Interbank Markets." Journal of Banking \& Finance 49: 27-40.

Ivashina, V., and D. Scharfstein. 2010. "Bank Lending during the Financial Crisis of 2008." Journal of Financial Economics 97 (3): 319-38.

Kiyotaki, N., and J. Moore. 1997. “Credit Cycles.” Journal of Political Economy 105 (2): 211-48.

Krishnamurthy, A., and A. Vissing-Jorgensen. 2011. "The Effects of Quantitative Easing on Interest Rates: Channels and Implications for Policy," Brookings Papers on Economic Activity, Fall 2011, No. 2.

Marrison, C. 2002. The Fundamentals of Risk Measurement. Boston, MA: McGraw-Hill.

Modigliani, F., and M. H. Miller. 1958. "The Cost of Capital, Corporation Finance and the Theory of Investment." The American Economic Review 48 (3): 261-97. 
Nouy, D. 2017. Banking Union: Safe and Sound Finance for Europe. Vienna: Speech at the RZB EU Sky Talk. 2 May 2017.

Poutineau, J.-C., and G. Vermandel. 2015. "Cross-border Banking Flows Spillovers in the Eurozone: Evidence from an Estimated DSGE Model." Journal of Economic Dynamics and Control 51: 378-403.

Quint, D., and P. Rabanal. 2014. "Monetary and Macroprudential Policy in an Estimated DSGE Model of the Euro Area." International Journal of Central Banking 10 (2): 169-236.

Rudebusch, G., and E. Swanson. 2008. The Bond Premium in a DSGE Model with Long-Run Real and Nominal Risks. San Francisco: Federal Reserve Bank of San Francisco, Working Paper Series 2008-31.

Rudebusch, G. D., and E. T. Swanson. 2012. "The Bond Premium in a DSGE Model with Long-Run Real and Nominal Risks." American Economic Journal: Macroeconomics 3 (4): 105-43.

Schmitt-Grohe, S., and M. Uribe. 2003. "Closing Small Open Economy Models." Journal of International Economics 61 (1): 163-85.

Smets, F., and R. Wouters. 2003. “An Estimated Dynamic Stochastic General Equilibrium Model.” Journal of the European Economic Association 1 (5): 1123-75.

Smets, F., and R. Wouters. 2007. "Shocks and Frictions in US Business Cycles: A Bayesian DSGE Approach.” The American Economic Review 97 (3): 586-606.

Townsend, R. M. 1979. "Optimal Contracts and Competitive Markets with Costly State Verification." Journal of Economic Theory 21 (2): 265-93.

Ueda, K. 2012. "Banking Globalization and International Business Cycles: Cross-Border Chained Credit Contracts and Financial Accelerators.” Journal of International Economics 86 (1): 1-16. van Rixtel, A., and G. Gasperini. 2013. Financial Crises and Bank Funding: Recent Experience in the Euro Area. Basel: Bank for International Settlements. BIS Working Papers No. 406.

Supplementary material: The online version of this article offers supplementary material (https:// doi.org/10.1515/bejm-2019-0097). 